\title{
Norbert Mojżyn
}

\author{
Uniwersytet Kardynała Stefana Wyszyńskiego w Warszawie
}

\section{Rajski ogród jako topos szczęścia w chrześcijańskiej komunikacji kulturowej}

\section{A paradise garden as the topos of happiness in Christian cultural communication}

\begin{abstract}
STRESZCZENIE:
Ogród jest ważnym elementem komunikacji kulturowej. W historii kultury pojawia się niemal równocześnie z cywilizacją agrarną. W komunikacji kulturowej najważniejszym jego składnikiem jest ewokacja szczęścia i rozkoszy (hortus voluptatis). Niemniej ważna jest symbolika tajemnicy wynikająca

z zamkniętego (ogrodzonego) charakteru przestrzeni (hortus conclusus). W komunikacji chrześcijańskiej ogród czerpał swoje pierwotne znaczenie religijne z Księgi Rodzaju (Eden), jednak w apokaliptyce chrześcijańskiej (a wcześniej żydowskiej) został utożsamiony z rzeczywistością eschatologiczną (raj niebieski). Jako taki odgrywał ważną rolę w założeniach klasztornych oraz w teologii i ikonografii jako symbol Maryi ilustrujący jej cnoty. Artykuł skupia się na chrześcijańskich konotacjach ogrodu jako toposu szczęścia na różnych płaszczyznach: filozoficznej (rajski ogród a koncepcja szczęścia), duchowej (ogród w życiu monastycznym), symbolicznej (cnoty

Maryi), artystycznej (ogród w twórczości literackiej Symeona Połockiego, pierwszego humanisty rosyjskiego).
\end{abstract}

SŁOWA KLUCZOWE:

ogród, szczęście, raj, komunikacja, kultura, symbol

\begin{abstract}
:
The garden is an important element of cultural communication. In the history of culture, it appears almost simultaneously with the agrarian civilization. In cultural communication, the most important component of it is the evocation of happiness and pleasure (hortus voluptatis). Nevertheless, the symbolism of mystery resulting from the closed (fenced) character of space (hortus conclusus) is important. In Christian communication, the garden drew its original religious meaning from the Book of Genesis (Eden), but in Christian (and earlier Jewish) apocalyptic, it was identified with the eschatological reality (heavenly paradise). As such, he played an important role in the monastic complexes and in theology and iconography as a symbol of Mary illustrating her virtues. The article focuses on the Christian connotations of the garden as the topos of happiness on different levels: philosophical (garden paradise and concept of happiness), spiritual (garden in monastic life), symbolic (virtue of Mary), artistic (garden in the literary output of Symeon Polocki, the first Russian humanist).
\end{abstract}

\section{KEYWORDS:}

garden, happiness, paradise, communication, culture, symbol 


\section{OGRÓD: OD NATURY DO KULTURY}

Od zarania dziejów człowiek próbował zrozumieć: czyim komunikatem, i jakiego rodzaju komunikatem, jest otaczająca go przyroda. Jednym z pierwszych czynników, mających wpływ na postrzeganie przyrody była obawa człowieka przed jej niezrozumiałymi siłami. Nie przypadkiem starożytne święte gaje w Grecji były miejscami kultu. Z czasem świadomość człowieka wzrastała, utwierdzając go w przekonaniu, że nie tylko ona może panować nad nim, ale że to on jest w stanie przyrodę sobie podporządkować. Przekonanie o wyższości człowieka nad naturą zdawało się dawać mu prawo do ingerencji w przyrodę i możliwość kształtowania jej według swoich potrzeb i zapatrywań. Ogród jako uporządkowana cząstka przyrody stanowiła nie tylko element ludzkiej gospodarki, ale budziła zachwyt estetyczny. Upatrywano w ogrodach źródeł i przykładów idealnego piękna. Biblijny ogród rajski bardzo silnie wpływał na wyobraźnię pokoleń żydów, muzułmanów i chrześcijan. Średniowieczni mnisi w swoich ogrodach klasztornych umacniali siłę ducha obrazem ziemskiego Edenu: utraconego i ponownie odzyskanego. Ogród ten miał być miejscem, gdzie natura odcięta od zewnętrznych zagrożeń miała szansę przypomnieć o utraconym raju, ale również być wezwaniem do udziały w przyszłym (eschatologicznym) raju - wiecznym szczęściu zbawionych. Początkowo zachwycono się przyrodą jako całością, jednak z czasem zaczęto skupiać się na jej fragmentach - widokach, krajobrazach, ogrodach. Natura stała się inspiracją dla sztuki. Z czasem zaczęto coraz bardziej świadomie kształtować środowisko naturalne, wplatając w naturalne krajobrazy elementy budowli, rzeźb i innych elementów sztuki ${ }^{1}$.

Celem niniejszego artykułu jest ukazanie i poddanie analizie obrazu relacji między naturalnymi i filozoficznymi (teologicznymi) koncepcjami szczęścia a ich kulturowym ekwiwalentem w postaci znaku (kodu), którym od zarania dziejów cywilizacji ludzkiej stał się ogród, jako miejscem bujnej wegetacji, dostatku i przyjemności. Przedmiotem analizy są znaki (alegorie) ogrodu zapisane przy pomocy rozlicznych dzieł literatury i plastyki w obrębie różnych kultur, szczególnie jednak na gruncie kultury chrześcijańskiej, których wytwarzanie i odczytywanie stanowi warunek trwania i integralności kultury chrześcijańskiej. Komunikowanie

${ }^{1} \mathrm{~K}$. Rozmarynowska, O wzajemnych relacjach człowieka, przyrody, ogrodu i miasta, „Estetyka i krytyka" 2007, nr 12 (1/2007), s. 13-16. 
bowiem rozumiane jako interakcja semiotyczna jest rozłożonym w czasie procesem kulturowym, który dostarcza danej społeczności udziału w rozumieniu, wytwarzaniu i przetwarzaniu znaków oraz modeli kulturowych².

Słowo ogród swoje brzmienie w języku polskim bierze od słowa „ogrodzenie”, pierwotne ogrody bowiem wydzielano z dzikiego otoczenia i odgradzano murem lub płotem. Tak zaprojektowane ogrody stanowiły uporządkowane, zaciszne i zamknięte miejsce uprawy wybranych roślin oraz przebywania ludzi i zwierząt. Odnosi się to przede wszystkim do ogrodów antycznych, średniowiecznych i renesansowych. Wraz z rozwojem sztuki ogrodowej zaczęto otwierać przestrzeń ogrodu, rezygnując z całkowitego wygradzania go z otoczenia, na rzecz cieszących się coraz większą popularnością ogrodów krajobrazowych. W efekcie pojęciu ogród nadano bardziej ogólne znaczenie, niż tylko „wygrodzone miejsce uprawne". Obecnie odnosi się ono do różnych form ukształtowania przestrzeni i funkcjonuje na równi z pojęciem założenie ogrodowe ${ }^{3}$. Ogród można definiować na wiele sposobów, w zależności od funkcji jaką spełnia w życiu człowieka. Najogólniej mówiąc, ogród „[...] stanowi układ przestrzenny w środowisku przyrodniczo-geograficznym, ukształtowany plastycznie i funkcjonalnie odpowiednio do przeznaczenia i programu użytkowego" ${ }^{\prime 4}$. Wydzieloną przestrzeń organizuje się w odniesieniu do naturalnych uwarunkowań, m.in. ukształtowania powierzchni, rzeźby terenu, klimatu czy gleby. Zrytmizowanie i usystematyzowanie w odpowiedni sposób naturalnych elementów krajobrazu - roślinności, wód, form naturalnych, pozwala uporządkować przestrzeń. Od człowieka zależy natomiast dobór form i roślinności w oparciu o koncepcję programową. Jedną z nich może być potraktowanie ogrodu jako miejsca uprawy roślin dekoracyjnych, albo wręcz samego w sobie dzieła sztuki, gdy twórca ogrodu ujmie elementy naturalne w jedną myśl kompozycyjną 5 .

${ }^{2}$ Edmund Ronald Leach, czołowy przedstawiciel brytyjskiej antropologii społecznej i komunikacji kulturowej, zaznaczał, że „ludzka komunikacja osiągana jest dzięki działaniom ekspresyjnym, które funkcjonują w postaci sygnałów, znaków i symboli”. Zob. E. Leach, Kultura i komunikowanie. Logika powiq̨zań symbolicznych. Wprowadzenie do analizy strukturalnej w antropologii społecznej, przeł. M. Buchowski, Warszawa 2010, s. 14.

${ }^{3}$ L. Majdecki, Historia ogrodów, Warszawa 1981, s. 10-11.

${ }^{4}$ Tamże, s. 9.

${ }^{5}$ A. Mitkowska, M. Siewniak, Tezaurus sztuki ogrodowej, Warszawa 1998, s. 165-166. 
Ogrody zakładano już w starożytnym Egipcie i Mezopotamii. Spełniały tam przede wszystkim funkcje użytkowe. Stanowiły miejsca wypoczynku, chroniły przed upałem, jednocześnie spełniały rolę ozdoby siedzib ludzkich. Głównym elementem ogrodu był zbiornik wodny (sadzawka), który wykorzystywano do ochłody i do nawadniania roślin, a który jednocześnie stanowił element dekoracyjny. Całość otaczały drzewa. Układ ogrodu był oparty na geometrycznym podziale przestrzeni ${ }^{6}$. Mistrzami w sztuce zakładania ogrodów okazali się Babilończycy. Słynnym ich obiektem ogrodowym były tzw. wiszące ogrody Semiramidy. Zostały wybudowane na polecenie króla Nabuchodonozora II w VI-VII wieku p.n.e. Wznoszono je na tarasach, na specjalnie stworzonych ziemnych konstrukcjach. Zwisające z tarasów pnącza sprawiały wrażenie, jakby ogrody wisiały w powietrzu 7 . W swoich ogrodach Babilończycy uprawiali kwiaty i warzywa oraz drzewa dające owoce; tu również pasły się bezpiecznie zwierzęta.

Charakterystyczne dla starożytnej Grecji i Rzymu były ogrody przydomowe. Ukształtowanie przestrzenne takiego ogrodu stanowiło powiązanie jego kompozycji z domem mieszkalnym tak, aby elementy ogrodu tworzyły całość kompozycyjną z budynkiem; stanowiły one centralny punkt domu i spełniały funkcje użytkowe - gromadzenie wody, pełniły również rolę estetyczną.

Postrzeganie ogrodu zmieniło się w okresie średniowiecza. Dominowało wtedy rozumienie ogrodu jako wydzielonej i ogrodzonej murem przestrzeni. Nie istniało powiązanie ogrodu z zabudową - stanowiły one odrębne części. Istotną rolę w projektowaniu przestrzeni zaczęły pełnić symbole, np. kształt krzyża. Dobór i rozmieszczenie elementów zagospodarowania ogrodu wynikały ściśle z narzuconej symboliki. Dotyczyło to nie tylko doboru gatunkowego roślin, ale również układu ścieżek czy elementów wodnych. Dominowała symbolika religijna. Na zagospodarowanie średniowiecznych ogrodów miała także wpływ ich funkcja użytkowa. Ogrody klasztorne obsadzano ziołami, które stosowano do produkcji leków

W okresie renesansu ogród stał się jeden z podstawowych elementów kompleksu mieszkalnego, którego ideałem jest harmonia i symetria oraz dopasowanie do kształtu terenu. Zachowywały cechy regularnego osiowego podziału, były

${ }^{6}$ L. Majdecki, Historia ogrodów, dz. cyt., s. 9.

${ }^{7}$ K. Kopiński, Wiszące ogrody Semiramidy, http://www.7cudow.ovh.org/stare-cuda/wiszace-ogrody-semiramidy.html, dostęp 31.08.2018.

${ }^{8}$ L. Majdecki, Historia ogrodów, dz. cyt., s. 60-62. 
tworzone na planie koła lub kwadratu9. Stworzono dwa główne rodzaje układów ogrodowych - osiowy i centralny ${ }^{10}$. Połączenie architektury i ogrodu stało się w założeniach teoretyków sztuki renesansu nowym wzorem kulturowym. Charakterystyczną formę stanowiły labirynty ze strzyżonych żywopłotów. Na uwagę zasługują również powstające od XVI wieku ogrody botaniczne, stanowiące specjalny zbiór roślin, służące celom naukowym ${ }^{11}$. Rośliny takie, jak bukszpan, cis czy niektóre odmiany wawrzynu bardzo łatwo poddawały się działaniom pielęgnacyjnym: można je było dowolnie strzyc, nadając kształty różnych brył geometrycznych. Moda na ars topiaria (czyli na sztukę kształtowania - przycinania drzew i krzewów) rozpowszechniła się m.in. dzięki słynnemu dziełu Francesca Colonny Hypnerotomachia Poliphyli (1467, wydana w Wenecji w 1499). Humaniści widzieli w geometrycznym ukształtowaniu form przyrody rozumowe ujarzmienie natury. Od czasów Kosmy I Medyceusza ogrody w Toskanii miały naśladować atmosferę intelektualną panującą w starożytnych Atenach; z tej racji były chętnie odwiedzane przez filozofów, uczonych i artystów. Miejsca takie, jak Careggi czy Poggio a Caiano stały się centrami neoplatonizmu a ogrody św. Marka we Florencji - swego rodzaju akademią sztuk. Z inicjatywy papieskiej powstały na Watykanie ogrody belwederskie stanowiące nowoczesny typ rezydencji letniej (zaprojektowane przez Bramantego). W Belwederze został umiejscowiony pierwszy od czasów antyku teatr na wolnym powietrzu, a także pierwsze muzeum. Belweder pozwolił na głęboką ingerencję w krajobraz oraz kontrolowanie natury i stworzenie z niej formy architektonicznej; miał dowieść wielkości geniuszu ludzi, którzy - w zgodzie z dyspozycją Księgi Rodzaju - mieli sobie uczynić ziemię poddaną (Rdz 1, 28). Z kolei Giacomo Barozzi da Vignola zaprojektował słynny ogród renesansowy w Bagnaia. Został on tak zaprojektowany, aby stworzyć szlak prowadzący od świata natury do świata kultury. Tuż obok wejścia znajdowała się fontanna z Pegazem w otoczeniu muz (symboliczny Parnas); dalej znajdowała się fontanna Kasztanów poświęcona boskiemu Jowiszowi, najwyższemu władcy nieba i ziemi oraz fontanna Bachusa stanowiąca aluzję do strumieni wina płynącego podczas mitycznego złotego wieku (ta część ogrodu miała przywoływać szczęśliwe czasy,

${ }^{9}$ A. Chrobok, Historia ogrodów, cz.6: Ogrody renesansu, http://www.miejskiogrodnik.pl/ porady-dla-ogrodu/item/490-historia-ogrodow-cz6-ogrody-renesansu, dostęp 31.08.2018.

${ }^{10}$ L. Majdecki, Historia ogrodów, dz. cyt., s. 97.

11 Tamże, s. 143. 
kiedy natura obdarowywała człowieka wszystkim, czego potrzebował); fontanna Murzynów ulokowana w środku kwadratowego ogrodu symbolizowała przyrodę ujarzmioną przez sztuki.

W okresie baroku wiodącą rolę odgrywała sztuka francuska, która stanowiła inspirację dla stylu całej epoki. Ogrody barokowe stanowiły odzwierciedlenie symetrycznych wnętrz pałacowych. Przestrzeń ogrodową dzielono w zależności od funkcji użytkowej poszczególnych miejsc. Ich wyposażenie nawiązywało do elementów wyposażenia pałacu ${ }^{12}$. Charakterystyczny był kontrast między poszczególnymi elementami kompozycji, np. płaskie partery ogrodu i wysokie masywy boskietów (drzewa i krzewy jednego gatunku). W założenia wkomponowywano również baseny, fontanny, zwierzyńce, różnorodne budowle ogrodowe oraz pomarańczarnie ${ }^{13}$.

XIX wiek przyniósł cały wachlarz ogrodów krajobrazowych opartych na przyrodniczych formach naturalnych (wprowadzono m.in. nieregularne grupy roślin, klomby i gaje), po współczesne tzw. małe ogrody zakładane najczęściej w przestrzeniach miejskich. W kompozycjach krajobrazowych rzadko stosowano rzeźby. Sporadycznie występowała rzeźba figuralna - wprowadzano głównie postaci z mitologii antycznej oraz wazy ogrodowe. Występowała natomiast duża różnorodność budowli ogrodowych, w tym głównie budowli użytecznych - szklarni, pawilonów, budynków dla zwierząt, budowli użytkowych - o charakterze gospodarczym, budowli ozdobnych - dla tworzenia założonych scen ogrodowych (altany, kioski, domki) oraz ruin.

Współcześnie popularne są ogrody okolicznościowe, np. tzw. ogrody pamięci. Odnoszą się one na ogół do rozwiązań historycznych, ponadto mogą być wyrazem hołdu dawnym wydarzeniom i postaciom (jest to miejsce, które powstało w hołdzie wszystkim osobom, które przez lata przyczyniły się rozwojowi polskiej botaniki). Ich założeniem jest stworzenie specyficznej atmosfery, która pozwala przywoływać wspomnienia. Można także uznać je za miejsce czci osób lub wydarzeń. Jednocześnie takie ogrody kultywują tradycje, zapoczątkowane wiele wieków wcześniej. Przykładem może być tutaj Ogród Botaniczny Uniwersytetu Warszawskiego jako ważny element przestrzeni wielkomiejskiej. Oprócz podstawowej

${ }^{12}$ K. Fortyniuk, Ogrody barokowe, http://www.ogrodyprojekty.com/pl_ogrody-barokowe,74.html, dostęp 31.08.2018.

${ }^{13}$ L. Majdecki, Historia ogrodów, dz. cyt., s. 189. 
funkcji dekoracyjnej spełnia on dodatkowe role: edukacyjną, rekreacyjną i naukową. Na niewielkim obszarze parku umieszczono elementy skłaniające obserwatora do refleksji, odnoszące się do przeszłości, działające na wyobraźnię i tworzące wyjątkową atmosferę, m.in. dzięki bogactwu roślinności. Warszawski Ogród Botaniczny pełni zatem nie tylko rolę estetyczną - zielonej enklawy w centrum miasta, ale wypełnia także zadanie świadectwa sztuki ogrodowej, przywołując wspomnienie o historii ${ }^{14}$.

Niezwykły urok ogrodów silnie oddziaływał na poezję, sztuki plastyczne, religię, filozofię, a nawet modę i codzienne obyczaje ${ }^{15}$. Choć same dawne ogrody na ogół nie zachowały się w niezmienionym do dziś stanie, to echo ich piękna przetrwało w utrwalonej poezji trubadurów, późnogotyckim malarstwie tablicowym, w dziełach niderlandzkich manierystów, spośród których można wymienić choćby Jana Breugla, Gillisa van Coninxloo czy Roelanta Savery. Biblijne fantasmagorie znalazły ucieleśnienie w słynnych francuskich i niderlandzkich tapiseriach, spośród których pewna ilość została sprowadzona przez Zygmunta II Augusta w celu dekoracji ścian komnat zamku na Wawelu („wawelskie arrasy”) ${ }^{16}$.

Jakkolwiek topos ogrodu miał ścisły związek z ziemskim, realnym miejscem, to ze względu na konotację odczuwania piękna, szczęścia, bujnej wegetacji, zmysłowej przyjemności i zadowolenia otrzymał wyraźny aspekt metafizyczny, czyniący zadość najgłębszym pragnieniom ludzkości - życia w pełni szczęścia. Jak pisał o raju Jean Delumeau: „Na tym błogosławionym obszarze bujność natury łączyła się z obfitością wody, z pięknymi zapachami, z wiosenną łagodnością klimatu, kiedy nie znano cierpienia, a ludzie żyli w zgodzie ze zwierzętami”"17.

${ }^{14}$ Por. J. Dudek-Klimiuk, Ogród botaniczny Uniwersytetu Warszawskiego - ogród pamięci i wyobraźni, „Architektura” 2-A/2012.

${ }^{15}$ Por. B. Zemanek, Ogród - raj odzyskany czy substytut natury, w: Ogród Pana. XVIII Międzynarodowe Seminarium Sacrum i Przyroda, red. J. Brusiło, Kraków 2010, s. 27.

${ }^{16}$ Zob. Zamek Królewski na Wawelu: Dzieje rajskie, sceny: Stworzenie Adama, Stworzenie Ewy, Bóg zapoznaje ze sobą pierwszych rodziców, Zakaz spożywania owocu, Grzech pierworodny, Wygnanie z raju, Bruksela, Arras około 1550. Kartony służące za podstawę arrasów wykonał Michael Coxcie (1499-1592), bordiury, wypełnione ornamentem zwanym niderlandzką groteską, otaczające pole środkowe każdego arrasu, zaprojektował nieznany artysta z kręgu Cornelisa Florisa de Vriendta (1514-1575) i Cornelisa Bosa (1506/10-1556). W górnych pasach umieszczono tablice z łacińskim napisem objaśniającym przedstawioną scenę. Zob. A. Misiąg-Bocheńska, Arrasy biblijne. Sceny z Księgi Genesis, w: Arrasy Wawelskie, Warszawa 1994, s. 67-171.

${ }^{17}$ J. Delumeau, Historia raju. Ogród rozkoszy, przeł. E. Bąkowska, Warszawa 1996, s. 10. 
W literaturze przedmiotu ogród, jak dotąd, był rozpatrywany głównie w pojedynczych, oddzielonych od siebie perspektywach badawczych. Przyrodnicy badali go pod kątem botaniki ${ }^{18}$, architekci - architektury krajobrazu ${ }^{19}$, filozofowie ${ }^{20}$ i historycy jako fenomen cywilizacyjny ${ }^{21}$, artyści i historycy sztuki ${ }^{22}$ a takie literaci i historycy literatury ${ }^{23}$ jako manifestację jednego z rodzajów sztuki itd. Tymczasem ogród jest ważnym zjawiskiem ogólnokulturowym, które odsłania wiele wątków i motywów towarzyszących życiu ludzi od tysięcy lat. Z tej racji ogrody stanowią wdzięczną przestrzeń do podejmowania badań interdyscyplinarnych, w tym szczególnie kulturowych nad komunikowaniem poprzez wielopłaszczyznowy topos znaczeń o charakterze egzystencjalnym, metaforycznym, duchowym, mistycznym itp. Wziąwszy pod uwagę antymodernistyczny zwrot w różnych nurtach współczesnej filozofii i humanistyki, objawiający się z jednej strony formułowaniem negatywnych programów „dekonstrukcji i rozproszenia” (J. Derrida), a z drugiej pozytywnymi programami „nowego filozofowania” (R. Rorty), a także różnego rodzaju współczesne projekty rewaloryzacji koncepcji odradzających transcendentalny wymiar ludzkiej egzystencji i zagubioną pamięć przeszłości sprawiają, że zwrócenie się ku historycznym i religijnym koncepcjom szczęścia w perspektywie biblijnego ogrodu rajskiego jako rodzaju komunikacji kulturowej uzyskuje w niniejszym tekście uzasadnienie.

${ }^{18}$ Por. J. Wilder, Ogród doskonały, Warszawa 2013.

${ }^{19}$ Por. K. Hodor, Podmiejskie rezydencje dworsko-ogrodowe w kształtowaniu krajobrazu mikroregionu Rowu Krzeszowickiego, Kraków 2011.

${ }^{20}$ Por. M. Borowska, Raj - miejsce czy droga? Wyobrażenia późnośredniowieczne a myśl współczesna, Izabelin 2004.

${ }^{21}$ Por. L. Majdecki, Historia ogrodów, Warszawa 2017; A. Zachariasz, Zieleń jako współczesny czynnik miastotwórczy ze szczególnym uwzględnieniem parków publicznych, Kraków 2006.

${ }^{22}$ Por. A. Mitkowska, M. Siewniak, Tezaurus sztuki ogrodowej, Warszawa 1998; Por. E. Guzikowska-Konopińska, Ogród japoński, Warszawa 2013; S. Kobielus, Florarium christianum. Symbolika roślin - chrześcijańska starożytność i średniowiecze, Kraków 2006; Tenże, Człowiek i ogród rajski w kulturze religijnej średniowiecza, Warszawa 1997.

${ }^{23}$ J.M. Rymkiewicz, Myśli różne o ogrodach, Warszawa 1968; S. Wysłouch, Literatura a sztuki wizualne, Warszawa 1994. 


\section{CHRZEŚCIJAŃSKA KONCEPCJA SZCZĘŚCIA}

Co oznacza szczęście ewokowane przez ogród? Chrześcijańska koncepcja szczęścia zbudowana została w zasadniczym zrębie na syntezie biblijnej wizji rajskiego ogrodu, jako miejsca (stanu) szczęśliwego obcowania człowieka z Bogiem z antyczną tradycją eudajmonistyczną ${ }^{24}$, którą zaszczepił na gruncie chrześcijańskim św. Augustyn. Starożytność grecko-rzymska stworzyła osobny nurt myśli związany ze szczęściem, tj. eudajmonizm (eudaimonia, dosł. „dobry duch”). W koncepcji eudajmonistycznej pełne szczęście jest związane z dobrem, doskonałością ludzkiej egzystencji. Grecko-rzymski eudajmonista rozumiał szczęście nie jako subiektywne zadowolenie, ale jako pewien obiektywny stan zachodzący na skutek właściwego postępowania (apatheia, ataraksja czy eutymia). Filozofia chrześcijańska podjęła tę myśl jeszcze u schyłku starożytności podkreślając, że samo zadowolenie nie jest istotą szczęścia, lecz jego następstwem: „najwyższe zadowolenie i niewypowiedziana radość jest koniecznym następstwem istoty szczęścia" (summa delectatio seu ineffabile gaudium ex essentia beatitudinis necessario sequitur). Szczęście jest koniecznym celem ludzkiego życia i opiera się na prawdzie. Św. Augustyn w De Trinitate pisał, że pragnienie szczęścia ma charakter uniwersalny i jest związane z poszukiwaniem prawdy. W dialogu Przeciw akademikom pisał: „Pragniemy być szczęśliwi. A więc niezależnie od tego, czy do szczęścia doprowadza nas znalezienie prawdy, czy też tylko pilne jej poszukiwanie, jeśli chcemy być szczęśliwi, musimy wysunąć na pierwszy plan szukanie prawdy"25.

\section{Chrześcijańska koncepcja szczęścia zbudowana została w zasadniczym zrębie na syntezie biblijnej wizji rajskiego ogrodu, jako miejsca (stanu) szczęśliwego obcowania człowieka z Bogiem z antyczną tradycją eudajmonistyczną.}

${ }^{24}$ Eudajmonizm, jako stanowisko etyczne głosił, że szczęście jest najwyższą wartością i celem życia ludzkiego.

${ }^{25}$ Św. Augustyn, Przeciw akademikom, przeł. K. Augustyniak, w: Dialogi filozoficzne, t. I, dz. cyt., s. 73. 
Augustyn w przeciwieństwie do pogańskich poprzedników dokonywał niezwykle szczegółowego rozważania podmiotowych warunków szczęścia. Według niego pierwszym warunkiem jest posiadanie tego, czego się pragnie. Nacisk został przez niego położony na podmiotowy warunek szczęścia: ten bowiem jest radosny, kto żyje tak, jak sam chce. Augustyn zastrzega słusznie, że grzesznik wprawdzie także żyje jak chce, ale nie można go obiektywnie nazwać szczęśliwym, ponieważ jego nieszczęściem jest posiadanie złych pragnień, nie mówiąc o ich realizacji. Dlatego Augustyn wprowadza drugi warunek: szczęśliwy jest ten, kto pragnie dobra. Jest to warunek wyższego rzędu, bowiem Augustyn zaznacza, że lepiej jest człowiekowi nie zaspokajać swoich pragnień, jeśli są złe, niż to czynić. Zatem szczęśliwy jest ten, kto ma wszystko, czego chce, ale jednocześnie usuwa zło z tego, czego pożąda ${ }^{26}$. Najważniejszy jest jednak trzeci warunek szczęścia, stanowiący jednocześnie cel ostateczny - to życie w perspektywie nieśmiertelności. Augustyn konkluduje, że każda próba osiągnięcia szczęścia w życiu doczesnym jest skazana na niepowodzenie, ponieważ jeśli w tym życiu nawet pragnie się tego, co dobre, to życie doczesne jest zbyt krótkie, aby swoim pragnieniem objąć wszystko, co w tym życiu jest dobre i to zrealizować. I na podstawie biblijnej opowieści o wygnaniu człowieka z raju dochodzi do wniosku, że niepowodzenie w osiągnięciu szczęścia w życiu doczesnym jest bezpośrednim następstwem grzechu pierworodnego opisanego w Księdze Rodzaju; tym samym odesłał do centralnego wydarzenia, które miało zaistnieć w biblijnym Edenie. Przypomnijmy, że w rezultacie biblijnego nieposłuszeństwa Adama i Ewy ludzie zostali wykluczeni z pierwotnego stanu szczęśliwości, poddani rygorowi śmierci, cierpienia i chorób ${ }^{27}$. Św. Grzegorz z Nyssy przywołując pierwotny raj pisał: „Był taki czas, kiedy chór istot duchowych stanowił jedno, wszystkie spoglądały ku jednemu koryfeuszowi, rozpościerając harmonię swego tańca, zgodnie z podawanym przezeń rytmem. Lecz wydarzył się grzech i zburzył natchnioną harmonię (...). Odtąd czekały one [tj. moce anielskie] czuwając u bram nieba"28.

Począwszy od Augustyna chrześcijańska teologia miała nieustannie przed oczami utracone przez grzech rajskie szczęście a ludzką grzeszność wpisaną

${ }^{26}$ Augustyn, O Trójcy Świętej, ks. XIII, V 8 (392).

${ }^{27}$ M. Koszkało, Koncepcja woli według św. Augustyna - perspektywa antropologiczna, „Roczniki Filozoficzne”, t. LXIV nr 3/2016, s. 31-32.

${ }^{28}$ Św. Grzegorz z Nyssy, In Psalm., PG, XLIV, 508 B, 509 A. Cyt. za: J. Danielou, Trójca Święta i tajemnica egzystencji, przeł. M. Tarnowska, Kraków 1994, s. 128. 
w naturę dziedziczoną przez dzieci tego świata. Augustyńska teologia grzechu pierworodnego miała dalekosiężne skutki. Za jej sprawą cała antropologia Zachodu została przesiąknięta duchem pesymizmu: ukształtował się pesymistyczny wizerunek człowieka, który sam z siebie nie jest w stanie osiągnąć szczęścia; jedyną szansą człowieka na prawdziwe szczęście jest odzyskanie raju, utraconego przez niewierność Bogu. Tym samym, prawdziwe szczęście związane zostało z przyszłą nieśmiertelnością (tj. życiem wiecznym, rajskim szczęściem, ewangelicznym Królestwem Bożym). Odtąd teologia chrześcijańska utożsamiła pełne szczęście z ostatecznym przeznaczeniem człowieka do obcowania z Bogiem w raju.

Nauka o szczęściu stanowi centralny punkt teologii moralnej i teorii czynów św. Tomasza z Akwinu. Dla Akwinaty pytanie o szczęście jest związane z przeznaczeniem i ostatecznym celem człowieka. Jego rozumienie szczęścia wyjaśnia już pierwsza część Sumy Teologicznej zatytułowana: „Cel ostateczny, czyli szczęście oraz uczynki ludzkie"29. Umieszczenie człowieka w Edenie jest dowodem, że Bóg powołał człowieka do szczęścia ze sobą. Grzech pierwszych ludzi zniweczył jednak pierwotny zamiar Boski, wskutek czego człowiek utracił ziemski raj. Jednak łaska Chrystusa, drugiego Adama, udziela na nowo szansy udziału w szczęściu rajskim, już nie ziemskim, ale niebieskim, na końcu czasów - jest to koncepcja raju odzyskanego. Punktem wyjścia jest więc biblijny ogród rajski zasadzony w Edenie - raj utracony; punktem dojścia - raj odzyskany - eschatologiczny. Prawdziwe szczęście jest nieskończone i wieczne. Jedynym dobrem mogącym całkowicie zaspokoić pragnienia ludzkie jest Bóg. Niewystarczający do szczęścia charakter dóbr ziemskich Tomasz uzasadnia empirycznie: codziennie pragniemy coraz to nowych dóbr pomimo, że sukcesywnie je zdobywamy i włączamy w swoje posiadanie, i to nawet dobra duchowe. Akwinata definiuje szczęście jako nieutracalne posiadanie doskonałego dobra, które zaspokaja całkowicie i trwale ludzkie pragnienie, wykluczając równocześnie wszelkie braki i zło ${ }^{30}$. Szczęście według św. Tomasza polega na tym, że „człowiek jednoczy się z jakimś dobrem, a im większe dobro posiada, tym większego szczęścia doświadcza. To szczęście będzie najpierw wynikiem osiągnięcia jakichś szczegółowych dóbr, a poprzez wszystkie te dobra,

${ }^{29}$ Zob. Św. Tomasz z Akwinu, Suma Teologiczna, t. 9: Cel ostateczny, czyli szczęście oraz uczynki ludzkie, przeł. W.F. Bednarski OP, Londyn [b.r.w.], http://www.katedra.uksw.edu.pl/ suma/Suma\%209.pdf; dostęp 5.06.2018.

${ }^{30}$ M. Klaja, Idea szczęścia u św. Tomasza z Akwinu, „Alma Mater”, s. 66. http://www2.almamater.uj.edu.pl/102/20.pdf; dostęp 5.06.2018. 
człowiek zbliża się do osiągnięcia dobra jak najbardziej ogólnego, a zarazem najbardziej trwałego" ${ }^{31}$, które można utożsamić z rajskim szczęściem. Prawdziwe szczęście - dodaje Akwinata - weryfikuje się trwałością i to jest prawdziwym dobrem dla człowieka. Jedynym trwałym dobrem jest Bóg, z tej racji szczęście polega na wiecznej kontemplacji Boga. Szczęście wieczne jest nagrodą za godziwe życie mocą odkupieńczego dzieła Chrystusa. Pełne szczęście człowiek może posiąść tylko tam, gdzie dobra nie przemijają i nie dewaluują się, tzn. w raju niebieskim (odzyskanym) $^{32}$.

\section{OGRÓD RAJSKI W HISTORII I MITOLOGII}

Ogród jako ucieleśnienie szczęścia zajmuje ważne miejsce w wielu mitach i wierzeniach religijnych, szczególnie w cywilizacjach Bliskiego Wschodu. W jałowym i pustynnym krajobrazie bliskowschodnim ${ }^{33}$ ogrody obszarów zw. Żyznego Półksiężyca - z dającymi cień drzewami, kwiatami, zapachami, ptakami, dźwiękami, strumieniami i sadzawkami - były symbolami szczęścia, bezpieczeństwa, schronienia, piękna, urodzaju, czystości i wiosennej świeżości.

W poszukiwaniu źródeł idei rajskiego ogrodu współczesna archeologia prowadzi nas aż do czasów cywilizacji przedagrarnej. Stanowisko archeologiczne w Göbekli Tepe w południowo-wschodniej Anatolii, u źródeł Tygrysu i Eufratu, którego początki sięgają co najmniej 9500 roku p.n.e. ${ }^{34}$, kryje pozostałości prehistorycznego sanktuarium, $\mathrm{w}$ tym - być może - ślady ucieleśnienia idei ogrodu rajskiego. Naukowcy nie mają wątpliwości, że miejsce to miało charakter kultowy, nie znaleziono bowiem żadnych śladów zamieszkania przez ludzi. Najbardziej imponującymi obiektami w Göbekli Tepe są kamienne kręgi o konstrukcji

${ }^{31}$ T. Stępień, Wprowadzenie do antropologii filozoficznej św. Tomasza z Akwinu, Warszawa 2013, s. 107.

${ }^{32}$ T. Urbaniak, III Studencka Sesja Naukowa na temat filozoficznych koncepcji szczęścia, „Studia Philosophiae Christianae” 10/2, 1974, s. 235.

${ }^{33}$ Rajem jako miejscem szczęśliwego wytchnienia, pokoju i bezpieczeństwa dla najdawniejszych koczowniczych plemion zamieszkujących tereny pustynne i stepowe były obfitujące w wodę i bujne w roślinność oazy.

${ }^{34}$ K. Schmidt, Göbekli Tepe. Eine Beschreibung der wichtigsten Befunde erstellt nach den Arbeiten der Grabungsteams der Jahre 1995-2007, w: "ArcheNova", Erste Tempel - fruehe Siedlungen. 12000 Jahre Kunst und Kultur. Ausgrabungen und Forschungen zwischen Donau und Euphrat, Isensee - Oldenburg 2009, s. 193. 
dużo bardziej złożonej, niż większość kręgów stawianych w Europie tysiące lat później. Składają się z koncentrycznie ustawionych dwumetrowych słupów kamiennych w kształcie litery T. Wiele z nich jest ozdobionych zoomorficznymi płaskorzeźbami. Niektóre z płaskorzeźb prawdopodobnie stanowią prahistoryczne symbole sakralne, a być może kryją w sobie jakąś opowieść zapisaną przy pomocy protopisma obrazkowego, gdyż niektóre wyryte na kamieniach symbole wydają się układać w logiczny ciąg znaków ${ }^{35}$.

Sanktuarium Göbekli Tepe zostało okrzyknięte przez badaczy i publicystów biblijnym rajskim ogrodem. Na płaskorzeźbach przedstawiających m.in. leopardy, węże, pająki czy ptaki można znaleźć wizerunki, które być może wiążą się z biblijną historią o Edenie ${ }^{36}$. Szczególnie interesujący jest w tym względzie niewielki kamień z wyrytymi piktogramami przedstawiającymi wyobrażenie węża, drzewa (pośrodku) i człowieka. Czyżby na tym kamieniu zapisana została mityczna historia o Drzewie Życia strzeżonym przez węża, broniącego ludziom dostępu ludziom do życiodajnych owoców? Analogiczne echo mitu rajskiego można odnaleźć na późniejszych tabliczkach glinianych z czasów cywilizacji Sumeru. W mezopotamskich mitologiach (począwszy od Sumeru przez Akad, Babilonię, Asyrię i Chaldeę) istniał mit raju jako bujnego ogrodu, obficie nawadnianego, w którym człowiek mógł odnaleźć schronienie i odpoczynek. Ukonkretniona idea raju pojawia się m.in. w mitach sumeryjsko-akadyjskich o Gilgameszu i Adapie. Zaskakujące porównania prowadzone przez sumerologów między tekstami Mezopotamii a późniejszymi tekstami religijnymi Żydów dotyczą przykładowo biblijnego stworzenia kobiety z żebra Adama, co zbiega się z sumeryjskim mitem o bogu Enki i Ninti, bogini stworzonej, by uśmierzyć ból z żebra władcy. Co ciekawe, słowo Nin-ti oznacza „pani dająca życie”, podobnie jak Ewa - „matka żyjących”. Takich analogii jest dużo więcej.

Göbekli Tepe odpowiada topografii mitycznej i biblijnej: znajduje się w dorzeczu wielkich rzek mezopotamskich: Tygrysu i Eufratu. Mimo, że jest to dziś jałowy, dziki, pustynny teren, to przed tysiącami lat Göbekli Tepe obfitowało w bujną

${ }^{35}$ Por. J. Peters, Göbekli Tepe: Agriculture and Domestication, w: The Archeological Record, s. 3066. https://www.researchgate.net/publication/260198406_Gobekli_Tepe_Agriculture_ and_Domestication, dostęp 16.08.2018.

${ }^{36}$ Por. K. Schmidt, Göbekli Tepe - the Stone Age Sanctuaries. New results of ongoing excavations with a special focus on sculptures and high reliefs, "Documenta Praehistorica XXXVII (2010)", s. 239-256 (szczególnie: rys. 15 i rys. 24). 
roślinność i dzikie zwierzęta, dopóki długotrwała susza (w latach 6 000-4 000 lat p.n.e.) nie spowodowała gwałtownego pustynnienia tych obszarów. W Göbekli Tepe doszło do wyniszczenia zasobów naturalnych, które pozwalały na błogie życie; ludzie w konsekwencji zostali zmuszeni do uprawy roli i hodowli. Czyżby w tej historycznej zmianie klimatu leżały źródła biblijnego Wygnania z raju?

Już ogrodom mezopotamskim nadawano sens kosmiczny - miały stanowić centra świata, serca ostatecznej rzeczywistości, w którym osiągalny jest stan quasi-boskości i nieśmiertelności. W prehistorycznej i protohistorycznej Europie ideę rajskiego ogrodu znali Celtowie, Germanie i Słowianie. Dla Celtów była to kraina wiecznej młodości, kraj Atrakondy Tir Sorcha, dla Germanów - Walhalla siedziba Odyna, dla Słowian - kraina bujnego ogrodu. Słowem, ogród jako przestrzeń obfitości, pełni, nieśmiertelności i szczęścia stanowił obrazowe ujęcie uniwersalnej tęsknoty człowieka za szczęściem i nieśmiertelnością ${ }^{37}$. Wyobrażano sobie, że człowiek został powołany do pierwotnej szczęśliwości, aby żyć w harmonii z bogami. Kiedy utracił ją na skutek ich gniewu, stał się istotą śmiertelną, a bogowie stali się niewidzialni; żył odtąd nie tylko wspomnieniem utraconej szczęśliwości, ale wiarą, że ma szansę odzyskania szczęścia w przyszłości jako nagrodę za etyczne i bogobojne życie ${ }^{38}$.

W okresie grecko-rzymskim topos rajskiego ogrodu wiązał się z tematem mitycznego Złotego Wieku ${ }^{39}$, Pól Elizejskich i Wysp Szczęśliwych. Rajem w mitologii grecko-rzymskiej był Elysion, kraina położona na zachodnich krańcach świata, gdzie miała panować wieczna wiosna; tam znajdowały się Wyspy Szczęśliwe, na których mieszkali bohaterowie wybrani przez Zeusa. Z rajskim ogrodem

${ }^{37}$ W Słowniku mitów i tradycji kultury W. Kopalińskiego odnajdujemy następującą definicję „raju”: „Raj (1) wg Biblii, Gen. 22, 8-14, Eden (hebr. Gan- edhen - 'ogród rozkoszy'), ogród Edenu, pierwsze miejsce pobytu pierwszego człowieka (...). (2) Według niektórych teologów pośredni stan a. miejsce gdzie dusze sprawiedliwych oczekują Sądu Ostatecznego. (3) Synonim Nieba, gdzie wg wielu religii wybrani - aniołowie i ludzie zbawieni - zażywać mają wiecznej szczęśliwości (...)”. Zob. W. Kopaliński, Słownik mitów i tradycji kultury, Warszawa 1987, s. 960 .

${ }^{38}$ Por. Z. Poniatowski, Mały słownik religioznawczy, Warszawa 1969, s. 369 (hasło „Raj”). Na marginesie warto zauważyć rezultaty badań pionierów tanatologii (Kübler-Ross, Moody, Ritchie, Ring, Sabom), którzy przytaczają relacje ludzi, którzy czasowo znaleźli się „po drugiej stronie życia” i przedstawiają swój pobyt w „rajskim ogrodzie”; interesujące są także przekazy medialne uzyskane metodą tzw. channelingu, w których zmarli opowiadali o swoich pośmiertnych doświadczeniach, jako pobycie w „cudownym ogrodzie”.

${ }^{39}$ Motyw Złotego Wieku. 
koresponduje także mityczny ogród Złotego Wieku. Tak go kreślił Platon w swoim Polityku: „[Ludzie] owoców mieli pod dostatkiem z drzew i z wielu innych roślin; one nie rosły z pracy rolników, tylko ziemia je wydawała sama z siebie"40. Motyw Złotego Wieku pojawiał się często w poezji Hezjoda, Wergiliusza, Owidiusza i Horacego. Ten ostatni, w XVI epodzie, przytaczał następujący obraz Wysp Szczęśliwych: „Rola tam daje plon corocznie, choć pług jej nie rusza, bez obcinania kwitnie winorośli pęd; ogrodnika tam nigdy oliwki kwiat nie zawiedzie i ciemne figi zdobią już macierzysty pień. Z dębu wyżłobień tam miód wypływa, a pluszcząc, krynica pośpieszną stopą w dół ze stoków skacze gór!”"11. W Pracach i dniach Hezjod i w Metamorfozach Owidusz kreślą mit Złotego Wieku, zgodnie z którym w czasach panowania boga Kronosa ludzie żyli niczym bogowie w wiecznym pokoju, dostatku i wiecznej młodości (nieśmiertelności), a ziemia dostarczała im wszelkiego pożywienia ${ }^{42}$. Odpowiednikiem ogrodu Złotego Wieku był ogród Hesperyd, w którym rosły złote jabłka, i który był zamieszkany przez smoka Ladona. Ogród Hesperyd to odzwierciedlenie odwiecznej idei Edenu, do którego dąży człowiek pragnący nieśmiertelności symbolizowanej przez złote jabłka.

\section{JUDEO-CHRZEŚCIJAŃSKA KONCEPCJA OGRODU RAJSKIEGO}

Raj w przekazie biblijnym został przedstawiony analogicznie do mezopotamskich mitów, jako bujny ogród, oaza na pustyni ${ }^{43}$. Z punktu widzenia tradycji teologicznej ogród rajski zajął bardzo ważne miejsce w Bożym objawieniu i w historii zbawienia. Zgodnie z przekazem biblijnym Bóg po stworzeniu świata i człowieka umieścił pierwszą parę ludzką w ogrodzie rajskim: „Wtedy to Pan Bóg ulepił człowieka z prochu ziemi i tchnął w jego nozdrza tchnienie życia, wskutek czego stał się człowiek istotą żywą. A zasadziwszy ogród w Eden na wschodzie, Pan

${ }^{40}$ Platon, Sofista i Polityk, przeł. W. Witwicki, Warszawa 1956, s. 133-134.

${ }^{41}$ Horacy, XVI epoda, przeł. T. Węclewski, Wielka Literatura Powszechna, t. V (Antologia. Cz. I. Literatury: chińska, japońska, indyjska, sumero-akkadzka, babilońska i asyryjska, egipska, starohebrajska, żydowska, arabska, perska, turecka, grecka, rzymska, łacińska wieków średnich, włoska, staro- i nowoprowancka, francuska), Nakładem Księgarni Trzaski, Everta i Michalskiego, Warszawa 1930, s. 571.

${ }^{42}$ Bodaj najsłynniejszą malarską wizję Złotego Wieku stworzył w 1530 r. Łukasz Cranach Starszy (Gemäldegalerie w Monachium).

${ }^{43}$ J. Seibert, Leksykon sztuki chrześcijańskiej. Tematy, postacie, symbole, przeł. D. Petruk, Kielce 2007, s. 269 (hasło: Raj). 
Bóg umieścił tam człowieka, którego ulepił. Na rozkaz Pana Boga wyrosły z gleby wszelkie drzewa miłe $\mathrm{z}$ wyglądu i smaczny owoc rodzące oraz drzewo życia w środku tego ogrodu i drzewo poznania dobra i zła. Z Edenu zaś wypływała rzeka, aby nawadniać ów ogród, i stamtąd się rozdzielała, dając początek czterem rzekom” (Rdz 2, 7-10). Rajski ogród został tu opisany jako „ogród w Edenie na wschodzie”, w którym znajdują się „wszelkie drzewa”, a wśród nich drzewo życia oraz drzewo poznania dobra i zła. Poza Księgą Rodzaju motyw ogrodu Eden (hebr. gan-den) pojawia się w Starym Testamencie wielokrotnie: w proroctwach Ezechiela, Izajasza i Joela, oznaczając szczęście, obfitość, płodność, urodzajność, radość i rozkosz. Ogród rajski oznacza uporządkowany świat (sacrum) założony przez Boga i uprawiany przez Boga w przeciwieństwie do świata poza ogrodem przestrzeni chaosu (profanum).

W okresie niewoli babilońskiej została dokonana przez proroka Ezechiela (VI w p.n.e.) znacząca reinterpretacja opowieści o ogrodzie rajskim. Raj był odtąd nie tylko wydarzeniem z początków stworzenia, ale wydarzeniem i miejscem w przyszłości - rajem odzyskanym, nadzieją dla uciemiężonych Żydów przebywających w niewoli babilońskiej. Ezechiel przedstawił obraz mesjanistycznego Edenu, który zakończy czasy niewoli i nieszczęść narodu wybranego. Zapowiada powrót do ojczyzny, odbudowę świątyni jerozolimskiej na kosmicznej górze, skąd wypłynie nowe źródło, zasilające cudowny ogród; będą w nim rosły drzewa, których liście nie więdną a owoce się nie wyczerpują.

O ile rajski ogród w Starym Testamencie był silnie związany z określonym miejscem i czasem bezpośrednio po stworzeniu człowieka, o tyle w Nowym Testamencie idea raju została przeniesiona w obszar pozaczasowy, geograficznie nieokreślony, wiecznie trwały i nieskończony. Już niektórzy uczeni żydowscy i potem chrześcijańscy - opowieść biblijną o ogrodzie rajskim starali się przekładać na płaszczyznę duchową i przenosić na płaszczyznę eschatologiczną. Jako pierwszy koncepcję alegoryczną na temat biblijnego opisu raju wysunął neoplatoński filozof żydowski żyjący w czasach Jezusa, Filon z Aleksandrii. Podobnie, jak Filon biblijny raj alegorycznie traktował Tertulian. Św. Augustyn wahał się z ostateczną interpretacją, raz uznawał ogród rajski za rzeczywistość historyczną, innym - za duchową. W średniowieczu anglosaski erudyta, Beda Czcigodny, jeden z najbardziej poczytnych autorów, nie wykluczał interpretacji alegorycznej, choć skłaniał się raczej ku dosłownemu odczytywaniu historii o rajskim ogrodzie: „Nie wątpijmy, że raj w którym znalazł się pierwszy człowiek, nawet jeśli się go 
pojmuje jako wyobrażenie obecnego Kościoła albo naszej przyszłej Ojczyzny, winien być pojmowany w sensie dosłownym. Było to miejsce rozkoszne, ocienione drzewami owocowymi, źródło wielkiej rzeki" ${ }^{44}$. Ku realistycznemu stanowisku skłaniał się także największy autorytet teologiczny średniowiecza, św. Tomasz z Akwinu. Akwinata komentując Sentencje Piotra Lombarda zadawał pytanie: „Czy raj ziemski jest miejscem cielesnym?”. Odpowiadał na to pytanie opierając się na stwierdzeniu św. Augustyna: „0 raju, w którym przebywali pierwsi ludzie, słusznie się rozumie, że oznacza on pewne rzeczy duchowe, chociaż nie podważa to prawdziwości historycznego opowiadania o cielesnym istnieniu raju"45. I dodawał: „Co powiedziano w Piśmie o raju ma charakter opowieści historycznej. Otóż we wszystkim, co mówi w ten sposób Pismo, należy upatrywać podstawę prawdziwości opowiadania i na tym trzeba budować interpretacje duchowe"46. Św. Tomasz twierdził: „Drzewo życia było więc drzewem rzeczywistym, gdyż jego owoce miały moc zachowywania życia (...), miało jednak i znaczenie duchowe, podobnie jak skała na pustyni była rzeczywistością materialną, która jednak symbolizowała Chrystusa" ${ }^{47}$. Ci, którzy nie podważali historycznego i realnego istnienia raju uważali, że znajduje się on na ziemi gdzieś w najdalszym zakątku Wschodu, i że obecnie jest niedostępny. Podróżnicy próbowali dotrzeć do tego raju, a wielcy odkrywcy epoki Odrodzenia mylnie sądzili, że byli na obszarach, na których zachowały się pewne ślady i uroki biblijnego rajskiego ogrodu ${ }^{48}$.

W doktrynie chrześcijańskiej utrwalił się pogląd, że rajski ogród ma znaczenie zarówno stanu pierwotnego (ziemskiego), jak i ostatecznego (niebieskiego) szczęścia, do którego Bóg powołuje człowieka. Współczesna teologia nie rozpatruje kwestii raju w kategoriach ani historycznych, ani geograficznych, to znaczy nie zastanawia się, kiedy był i gdzie był rajski ogród opisany w Biblii. Odkrywa natomiast prawdę, że w opisie ogrodu rajskiego, który Bóg stworzył zaraz po dziele stworzenia świata i człowieka, zawiera się zamysł włączenia człowieka

${ }^{44}$ Cyt. za: J. Delumeau, Historia raju, dz. cyt., s. 23.

${ }^{45}$ Św. Augustyn, O Państwie Bożym, ks. XIII. Cyt. za: J. Delumeau, Historia raju ..., dz. cyt., s. 24.

${ }^{46}$ Św. Tomasz z Akwinu, Suma Teologiczna, Człowiek, I, Q 102. Cyt. za: J. Delumeau, Historia raju..., dz. cyt., s. 24.

${ }^{47}$ Tamże.

${ }^{48}$ Lokowanie mitycznego ogrodu rajskiego na ziemi było w różnych tradycjach religijnych i mitologicznych rzeczą dużej wyobraźni: począwszy od najdalszych zakątków ziemi, po niedostępne góry, księżyc, planety, kosmos. Ten ostatni najczęściej oddaje pojęcie naszego „nieba”. 
w przestrzeń Boskiego szczęścia. Wnioskuje się to z samych słów Jezusa, który na krzyżu obiecał dobremu łotrowi wejście do raju: „Zaprawdę powiadam ci: „Dziś ze Mną będziesz w raju «" (Łk 23, 43). Na tej podstawie św. Jan Chryzostom w kazaniu wielkopiątkowym zaznaczał: „Wygnałeś nas z raju i do raju wzywasz”49. Św. Atanazy Wielki na tej samej podstawie stwierdzał w jednej ze swych homilii: „[Chrystus] otworzył przed nami bramy raju, skąd Adam został wygnany i gdzie wszedł znowu pod postacią łotra, tak jak mówi Pan: »Dziś jeszcze będziesz ze mną w raju«. Tam też został porwany święty Paweł”50.

\section{W doktrynie chrześcijańskiej utrwalił się pogląd, że rajski ogród ma znaczenie zarówno stanu pierwotnego (ziemskiego), jak i ostatecznego (niebieskiego) szczęścia, do którego Bóg powołuje człowieka.}

W takiej perspektywie nie szuka się już rajskiego szczęścia z dala od człowieka, ale w nim samym, w jego wnętrzu; przy pomocy łaski Bożej dokonuje się proces przywracania przyjaźni i przymierza z Bogiem oraz odnajdowania pełni szczęścia poprzez pogłębione życie duchowe. Za wyraz takiego poszukiwania można uznać uduchowioną poezję Efrema Syryjczyka (Hymny o raju), który na sposób poetycko-oniryczny opisywał rajski ogród ${ }^{51}$ : jako „ogrodzone miejsce,

${ }^{49}$ Grzegorz z Nyssy, Oratio in baptismum Christi, PG46, kol. 600; Cyt. za: J. Delumeau, Historia raju..., dz. cyt., s. 31.

${ }^{50}$ Św. Atanazy, Expositio fidei, I, PG 25, kol. 201; Cyt. za: J. Delumeau, Historia raju ..., dz. cyt., s. 30-31.

${ }^{51} \mathrm{~W}$ poetycko-duchowym podejściu do kwestii rajskiego ogrodu wybrzmiewa echo tradycji helleńskiej. Jakkolwiek recepcja poglądów antycznych na temat Złotego Wieku i Wysp Szczęśliwych natrafiła na silny opór pisarzy wczesnochrześcijańskich (byli oni krytycznie nastawieni nie tylko do mitologii, ale całej spuścizny antyku), to niektórzy z nich dostrzegali jednak pewną wartość niektórych twierdzeń i pojęć antycznych, traktując je bądź to jako rzekome zapożyczenia z tradycji biblijnej bądź jako daleką jej trawestację. Znamienna jest w tym względzie Przestroga dla Greków, przypisywana Justynowi Męczennikowi (zm. 165), której autor stwierdza, że Homer zapoznał się z Pięcioksięgiem Mojżesza podczas pobytu w Egipcie. Homer - według Justyna - miał biblijny opis ogrodu rajskiego przetworzyć w fikcję literacką: 
gdzie [są] milczące drzewa figowe [...], jasne siedziby, wonne źródła”. A odnosząc te poetyckie obrazy do raju eschatologicznego przestrzegał, aby rozumieć je na sposób duchowy: „oczyma duszy - pisze - widzę raj [...]. Uduchowionym przystoją oczy duchowe" 52 .

\section{OGRÓD RAJSKI W MISTYCE}

W życiu duchowym mostem i łącznikiem między rajem utraconym i odzyskanym jest Maryja. Interpretacja mariologiczna rajskiego ogrodu łączy ogród rajski z osobą Maryi oraz - za jej pośrednictwem - z całym wierzącym ludem, czyli Kościołem (wychodząc od całkowicie darmowego wybrania, przez które Przedwieczny związał się z Nią i całą ludzkością). Maryja jest jedną z niewielu niewiast, które uzyskały status znaku, który od dwóch tysięcy lat głęboko przenika kulturę i życie religijne ${ }^{53}$. Maryja komunikuje w tajemnicy życia chrześcijańskiego przede wszystkim cnotę wiary, pokory, chrześcijańskiej doskonałości i pełni ${ }^{54}$. Ponieważ pełnia i doskonałość wiązała się w średniowieczu z pięknem, to Maryja stała się tota pulchra, jako najpiękniejszy kwiat ogrodu-Kościoła uprawianego przez Boskiego Ogrodnika ${ }^{55}$.

\section{W życiu duchowym mostem i łącznikiem między rajem utraconym i odzyskanym jest Maryja.}

Na początku XV wieku w literaturze religijnej i teologicznej oraz w ikonografii powstaje wywodzący się z Księgi Pieśni nad Pieśniami temat Maryi jako „ogródka rajskiego". Oblubieniec z tej księgi biblijnej, utożsamiany w egzegezie

„Postarał się następnie, aby ogród Alkinoosa stał się obrazem raju ziemskiego, opisując ogród wiecznie kwitnący i pełen owoców". Zob. Św. Justyn Męczennik, Cohortatio ad Grecos, PG 6 kol. 294. Cyt. za: J. Delumeau, Historia raju, dz. cyt., s. 15.

${ }^{52}$ Efrem Syryjczyk, Hymny o raju, Cyt. za: J. Delumeau, Historia raju, dz. cyt., s. 16, 20.

${ }^{53}$ M. Warner, Sola fra le donne. Mito e culto di Maria Vergine, Palermo 1980, s. 19.

${ }^{54}$ B. Forte, Maryja ikona tajemnicy, przeł. B. Widła, Warszawa 1999, s. 17.

${ }^{55}$ Przypomnijmy, że sam Jezus po swoim zmartwychwstaniu ukazał się Marii Magdalenie jako ogrodnik (scena Noli me tangere). 
chrześcijańskiej z samym Chrystusem, mówi: „Ogrodem zamkniętym jesteś, siostro ma, oblubienico, ogrodem zamkniętym, źródłem zapieczętowanym. (...) Jesteś źródłem ogrodów, zdrojem wód żywych spływających z Libanu" (PnP 4,12n). Tekst ten był w średniowieczu odczytywany w kluczu mariologicznym i eklezjologicznym. Zamknięty ogród (hortus conclusus) symbolizuje dziewictwo Maryi, objęcie i posiadanie wielu cnót i zachowanie przez Nią wolności od grzechu oraz orędownictwo Matki Boga w niebie za ludźmi; w odniesieniu do Kościoła - pilne strzeżenie depozytu wiary ${ }^{56}$. Piewcą cnót Maryi jako ogrodu zamkniętego był cysters, św. Bernard z Clairvaux. Także Honoriusz z Autun uznawał hortus conclusus za symbol Maryi i Kościoła ${ }^{57}$, wyjaśniając, że zamknięcie ogrodu symbolizowało ochronę Maryi przed grzechem ${ }^{58}$.

Liczne kwiaty i inne rośliny w ogrodzie Maryi nabierają znaczenia mistycznego ${ }^{59}$. Według generalnych przekonań średniowiecznych kwiaty pachnące miały moc odstraszania demonów a rośliny kolczaste czy włochate przyciągania ${ }^{60}$. Wśród kwiatów najpiękniej pachnących była róża. Maryję nazywano „ogrodem różanym”, „różą wspaniałą”, „różą mistyczną”, „różą bez kolców” (rosa sine spina wierzono, że kolce wyrosły róży dopiero po grzechu pierworodnym) ${ }^{61}$. Różami Matki Bożej i różami bez kolców nazywane były również piwonie ${ }^{62}$.

${ }^{56} \mathrm{~W}$ scenach malarskich obrazujących ten fragment Maryja siedzi na ławce z darni w ogródku różanym. Najczęściej przedstawiana jest z Dziecięciem Jezus, czasem ze świętymi, szczególnie ze świętymi dziewicami, które stoją na kwiecistej łące. Łąkę i postaci otacza mur z krenelażem, żywopłot lub płot z zamkniętą bramą. Zob. J. Seibert, Leksykon..., dz. cyt., s. 269-270.

${ }^{57}$ S. Kobielus, Człowiek i ogród rajski w kulturze religijnej średniowiecza, Warszawa 1997, s. 142.

${ }^{58}$ J. Delumeau, Historia raju..., dz. cyt., s. 117.

${ }^{59}$ T. Basiura, Ogród Maryi. Atlas roślin maryjnych, Kraków 2018.

${ }^{60} \mathrm{~J}$. Jagla, Święte czy diabelskie? Symboliczny wizerunek roślin kłujących, kolczastych i ciernistych $w$ malarstwie europejskim, w: Rośliny lecznicze $w$ kulturze, nauce i sztuce. Materiały z konferencji z okazji 25-lecia „Ogrodu roślin zdatnych do zażycia lekarskiego” w Muzeum Rolnictwa im. Ks. K. Kluka w Ciechanowcu, Ciechanowiec 2009, s. 67n.

${ }^{61}$ S. Kobielus, Florarium..., dz. cyt., s. 184-189.

${ }^{62}$ Są one przedstawione m.in. na obrazie Mistrza Górnoreńskiego obok innych roślin. Widzimy tu poziomki - symbol niewinności Maryi, lilie - znak czystości, irysy - symbol smutku, konwalie, babki zwyczajne - znak pokory, pierwiosnki - znak Maryi jako pierwszej i błogosławionej między niewiastami, malwy, mniszki lekarskie - symbole uzdrowicielskiej mocy Maryi, szałwia - święty kwiat, który miał ukryć Świętą Rodzinę przed oprawcami w drodze do Egiptu, goździki, róże - znaki męki Jezusa i cierpienia Maryi. Zob. Tamże. 
Duchowość maryjna nie przypadkiem ukształtowała się w kręgach monastycznych, w których równolegle rozwijała się kultura ogrodowa. W dawnych zakonach opartych na zasadzie stabilitas loci - np. według Reguły św. Izydora z Sewilli (zm. 636) ogrody funkcjonowały obligatoryjnie ${ }^{63}$. W odniesieniu do życia zakonnego opat Gillerbert (zm. 1172) wykazywał, że hortus conclusus w życiu zakonników należy rozumieć w ten sposób, że hortus oznacza „rozkosz”, a conlusus „wewnętrzną karność”. W takim ogrodzie rodzą się liczne pąki dzieł duchowych o różnorodnych zapachach, rosną w nim fiołki wyznawców, róże męczenników, lilie dziewic, złoto aniołów, które przeradza się w wieczny blask, trud wyznawców przemienia się w nieskazitelny szkarłat, krew męczenników w królewską purpurę, czystość dziewic w piękność lilii ${ }^{64}$.

Najczęściej średniowieczne klasztory zaopatrzone były w wewnętrzny ogród zwany wirydarzem. Był on nie tylko warzywnikiem, ale również miejscem przeznaczonym do osobistej kontemplacji i modlitwy; był miejscem poszukiwania odpowiedzi na najważniejsze pytania filozoficzne i egzystencjalne ${ }^{65}$. Miał na ogół kształt kwadratu i był podzielony dróżkami w kształcie krzyża na cztery części. Na przecięciu dróżek z reguły znajdowała się studnia (fontanna), która symbolizowała źródło życia albo drzewo - symbol rajskiego drzewa poznania dobra i zła albo Chrystusowego drzewa krzyża (arbor vitae) ${ }^{66}$. Z tej racji ogrody klasztorne były wprost pojmowane jako toposy biblijnego Edenu i rosnącego w nim Drzewa Życia.

Bogaty materiał pozwalający prześledzić powstanie i ewolucję założeń ogrodu klasztornego zawiera hagiografia i ikonografia średniowieczna. Dla przykładu jeden z najważniejszych zabytków literatury staroruskiej: Pateryk Kijowsko-Pieczerski (wydany drukiem w Kijowie w 1661) ${ }^{67}$, w warstwie ilustracyjnej wyraź-

${ }^{63}$ S. Kobielus, Człowiek..., dz. cyt., s. 139.

${ }^{64}$ Tamże, s. 144.

${ }^{65}$ Kultura ogrodowa miała bezpośrednie przełożenie na kształt życia mniszego i odwrotnie, na wygląd ogrodu klasztornego wpływał sposób życia poszczególnych kongregacji zakonnych: inaczej wyglądał ogród mnichów prowadzących życie wspólnotowe (np. benedyktynów), a inaczej eremitów (np. kamedułów). Pieczołowicie pielęgnowane ogrody klasztorne stanowiły topos „duchowego ogrodu, który winien rozkwitać w każdej duszy”. Zob. Antologia mistyków franciszkańskich, red. S. Kafel, t. 3, Warszawa 1987, s. 11.

${ }^{66}$ L. Impelluso, Ogrody i labirynty, przeł. A. Wójcicka, Warszawa 2009, s. 21.

${ }^{67}$ Pierwsze drukowane wydanie Pateryku w języku cerkiewno-słowiańskim ujrzało światło dzienne „z polecenia i z błogosławieństwem” pieczerskiego archimandryty, Innocentego Gizela, wybitnego teologa i działacza kultury rusińskiej w XVII-wiecznej Rzeczypospolitej. 
nie przedstawia klasztor jako ogród rajski. Pateryk został bogato zilustrowany grafikami przez mistrza izografii - Ilję. Na jednej z nich ukazany jest budynek cerkwi z którego wyrastają pędy obsypane kwiatami, którymi są święci mnisi pieczerscy; po bokach cerkwi stoją święci założyciele ławry: Antoni i Teodozy ukazani całopostaciowo ${ }^{68}$. W artystycznej świadomości izografa powstał tu dekoracyjny system komunikacyjny, w centrum którego znajduje się skomplikowana, wieloczłonowa alegoria ogrodu rajskiego, odpowiadająca potrzebom stworzenia uniwersalnego modelu życia chrześcijańskiego prowadzącego od raju utraconego do raju odzyskanego ${ }^{69}$.

\section{OGRÓD W KOMUNIKACJI KULTUROWEJ}

W chrześcijańskim światopoglądzie symbole i alegorie dominują nad sensem bezpośrednim stanowiąc istotny kanał komunikacji religijnej. W takim ujęciu ważne jest odniesienie symboli do danych biblijnych, do bogactwa relacji pierwotnej i normatywnej wiary ${ }^{70}$. Temat ogrodu rajskiego jako toposu szczęścia doskonale nadawał się, by realizować potrzebę nauczania i poruszania uczuć (łac. docere et permovere), przy wykorzystaniu bogatego arsenału narzędzi kulturowych służących zasadzie rozkoszowania (delectare), rozweselania serca, czyli dawania uciechy, słodyczy i radości. Plotyn w III Enneadzie stwierdzał, że kosmos jest na wzór ogrodu dziełem Poety-Stwórcy (Kreatora) ${ }^{71}$. Poezja znacząco wpłynęła na akceptację, a później na syntezę chrześcijańskiej i antycznej wizji ogrodu ${ }^{72}$,

${ }^{68} \mathrm{Na}$ grafice Mistrza Ilji, datowanej na 1658 rok, po raz pierwszy spotyka się kompozycję z ukorzenionym w kijowskiej cerkwi uspieńskiej pędem, który wkopuje łopatą św. Antoni a podlewa wodą z dzbana św. Teodozy. cyt., s. 75-94; w związku z tym należy odnotować zbieżność ogólnej struktury kompozycyjnej omawianej ikony i całego szeregu opraw książkowych II połowy XVII - początku XVIII wieku zarówno ukraińskiej, jak i rosyjskiej roboty. Na temat tych redakcji zob. D.I. Abramowicz, Issledowanije o Kijewo-Pieczerskom Patierikie kak istoriko-litieraturnom pamiatnikie, Sankt-Pietierburg 1901, rozdz. 2, s. 96-120; W.N. Pierietc, Kijewo-Pieczerskij Patierik $w$ polskom i ukrainskom pieriewodie, w: IV Mieżdunarodnyj sjezd sławistow. „Słowianskaja fiłołogija”, wyd. III, Moskwa 1958, s. 176-177.

${ }^{69}$ Zob. A.A. Morozow, Iz istorii osmyslenija niekotorych emblem w epochu Renesansa i Barokko, w: Mif, Fołkłor, Litieratura, Leningrad 1978, s. 38-67.

${ }^{70}$ B. Forte, Maryja..., dz. cyt., s. 21.

${ }^{71}$ E. Garin, Moyen Age et Renaissance, Paris 1969, s. 45.

${ }^{72}$ Echo scholastycznej syntezy tradycji chrześcijańskiej i antycznej odnajdujemy jeszcze w XVII wieku na wschodnich kresach łacińskiej reipublicae litterarum. W 1632 roku 
tak iż po kilku wiekach Dante Alighieri w Czyśćcu (XXXII, 73) w Boskiej komedii, przywołując obraz biblijnego rajskiego ogrodu mógł marzyć, aby: „oglądać pąki jabłoni, która swym owocem wywołuje pożądanie aniołów, i sprawia w Niebie ustawiczne wesele". To błogosławione miejsce, które Bóg dał człowiekowi jako rękojmię szczęścia, wypełnione było dąbrową o gęstych liściach chroniących ludzi przed żarem słońca; wielka tam panowała rozmaitość zieleni, wśród której „ptaszęcy rój na każdym drzewie z pośrodku liści nuci radośnie”73.

Poetyckim obrazom rajskiego ogrodu towarzyszyły „malarskie poematy”. Ikonografia chrześcijańska podjęła się wizualizacji różnych wątków historii rajskiej. Sceny plastyczne przedstawiające Adama i Ewę w ogrodzie Eden z reguły koncentrują się na podkreślaniu wydarzeń zbawczych redukując znaczenie flory rajskiego ogrodu (najczęściej do jednego drzewa - poznania dobra i zła), jak to zostało przedstawione choćby na płaskorzeźbie brązowych słynnych drzwi bpa Bernwarda w Hildesheim (XI w.). Dopiero od początku XV wieku wraz z nurtami humanizmu i odrodzenia zainteresowanie rozszerza się na przedstawianie roślinności rajskiej. Krajobraz nabiera coraz większej samodzielności jako locus amoenus („przyjemne, urokliwe miejsce”) przysłaniając niekiedy podstawową treść religijną przedstawień ogrodów rajskich. Nicolas Poussin w cyklu pór roku (Luwr, ok. 1600) przedstawił jako „ziemski raj” - wiosnę ${ }^{74}$. Równolegle rozwija się zainteresowanie samą sztuka ogrodnictwa - powstają idylliczne ogrody z bogactwem roślin.

Ważnym elementem opisu biblijnego ilustrowanego przez malarzy było Wygnanie z raju, co znakomicie przedstawia słynna mozaika z Monreale (XII w.),

w Kijowie powstał panegiryczny zbiór łączący chrześcijańskie symbole z obrazami mitologii antycznej, tzw. Ewcharistipion albo Wdiacznost', w którym studenci kursu retoryki kolegium mohylańskiego opisywali dwa „Ogrody umiejętności”. W pierwszym, „Helikonie”, wyrasta osiem korzeni: gramatyka, retoryka, dialektyka, arytmetyka, muzyka, geometria, astronomia i ósmy - korzeń wszystkich umiejętności - teologia. Drugi ogród - „Parnas” - został ozdobiony dziewięcioma latoroślami, to jest dziewięcioma muzami. Dobrymi robotnikami w tych ogrodach są: teolog, retor, matematyk, poeta, muzykant itd. „Królową rajskich ogrodów” i „Patronką wszystkich nauk" jest tu sama Matka Boża. Zob. F. Titow, Tipografija Kijewo-Pieczerskoj ławry. Istoriczeskij oczerk (1606-1616-1721), t. I, Priłożenija, Kijew 1918, s. 293-304. „Rozmaitymi kwiatami słów” obsadzał „Ogród Bogurodzicy” również Antoni Radziwiłowski, autor zbioru kazań Ogorodok Marii Bogorodicy (Kijów 1676). Zob. A. I. Sobolewskij, Pieriewodnaja litieratura Moskowskoj Rusi XIV-XVII wiekow, Sankt-Pieterburg 1903, s. 252.

${ }^{73}$ Cyt. za: J. Delumeau, Historia raju, dz. cyt., s. 49.

${ }^{74}$ J. Seibert, Leksykon ..., dz. cyt., s. 269. 
ukazująca cherubina pełniącego straż przy wejściu do Edenu i wyrzucającego prarodziców z rajskiego ogrodu. Wygnanie pierwszych ludzi dokonało się przez bramę raju ziemskiego; w ikonografii chrześcijańskiej zarówno wygnanie, jak i powrót do raju niebieskiego dokonuje się przez bramę - portal kościoła. W Apokalipsie św. Jana (rozdz. 21-22) zbawieni otrzymują obietnicę udziału w niebieskim Jeruzalem, którego bramy zaopatrzone są w dwanaście bram. W czasach gotyku raj często przedstawiano jako katedrę (obrazującą Kościół), której portalowi głównemu przypisywano znaczenie „bramy niebios”75. Na lewym skrzydle Sądu Ostatecznego Hansa Memlinga droga zbawionych do raju prowadzi przez późnogotycki portal, z przedstawieniem Chrystusa na majestacie w tympanonie, w nawiązaniu do słów „Ja jestem bramą owiec. Jeżeli ktoś wejdzie przeze Mnie będzie zbawiony" $(J 10,9)$. W szczycie bramy wyobrażono stworzenie Ewy. Oba te wyobrażenia przedstawiają myśl, że bramy niebios zamknięte przez grzech pierworodny, zostały znów otwarte dzięki dziełu drugiego Adama - Chrystusa i drugiej Ewy - Maryi ${ }^{76}$.

Gotycki portal jako brama zbawienia był niewątpliwie poddany ideom świętej geometrii opartej na proporcjach liczbowych wyłożonej w dziełach Augustyna i Boecjusza (echa neoplatonizmu i pitagoreizmu) ${ }^{77}$. Podobnie, jak starożytni pitagorejczycy, byli oni zdania, że o doskonałości i pięknie czegokolwiek stanowią liczby budujące harmonię ${ }^{78}$. Uważali, że kontemplacja piękna zbliża do prawdy, przynosi więc szczęście ${ }^{79}$. W tym kontekście interesująca jest wizja chrześcijańskiego raju wypełnionego złocistym blaskiem i anielską muzyką, w których przebywają zbawieni oglądający Boga „twarzą w twarz”. Raj ma być tu miejscem

${ }^{75}$ M. Borowska, Raj..., dz. cyt., s. 62.

${ }^{76}$ B. Dąb-Kalinowska, Ziemia, piekło, raj, Warszawa 1994, s. 194.

${ }^{77}$ Sekstus Empiryk pisał: „Żadna sztuka nie powstaje bez proporcji, a proporcja leży w liczbie. Wszelka więc sztuka powstaje przez liczbę". Cyt. za: B. Sudak, Matematyczna koncepcja muzyki, Zielona Góra 1992, s. 248.

${ }^{78}$ Jak pisze w odniesieniu do doskonałych (rajskich) proporcji katedr gotyckich von Simson: „[Według Augustyna] zbawienie miało być wieczną symfonią (...). Współbrzmienia muzyczne - również te zawarte w uchwytnych dla oka proporcjach dzieł ludzkiej ręki - mają udział w wiecznej harmonii, która je przenika". Zob. O. Von Simson, Katedra gotycka. Jej narodziny i znaczenie, przeł. A. Palińska, Warszawa 1989, s. 42.

${ }^{79}$ M. Borowska, Raj..., dz. cyt., s. 42. 
„muzyczno-tanecznej harmonii” ukazywanej w chrześcijańskiej ikonografii ${ }^{80}$ często przez śpiewających i grających aniołów ${ }^{81}$.

Stosowanie zasad świętych proporcji było nawiązaniem do pierwotnego kosmosu wyrwanego przez Stwórcę z odmętów chaosu, ewokującego stan rajskiej harmonii ${ }^{82}$. Ten kosmologiczny aspekt odzwierciedlany w średniowiecznej plastyce przez mozaiki i miniatury ukazujące Stwórcę posługującego się cyrklem i wagą miał istotne znaczenie $w$ formowaniu się geometrii sakralnej ${ }^{83}$. Ogrody rajskie przyjmowały w ikonografii na ogół kształt kwadratu, w mniejszym stopniu koła lub oktogonu, przywołując określone znaczenia metafizyczne i mistyczne ${ }^{84}$. Z uwagi na to, że o kwadratowym planie niebieskiego Jeruzalem wprost mówi Apokalipsa, kwadrat powszechnie przyjął się do symbolizowania raju niebieskiego, czyli oczekiwanego raju „końca czasów”. Oktogony, to figury przejściowe między kwadratem i kołem; powstawały z nałożenia dwóch kwadratów; z racji posiadania ośmiu boków symbolizowały dzień zmartwychwstania (ósmy dzień, tj. 7+1), zbawienie, życie wieczne, szczęście eschatologiczne ${ }^{85} . W$ kształcie kolistym, doskonałym, wyobrażano w średniowieczu przede wszystkim raj utracony, czyli ziemski, historyczny. W słynnych Bardzo bogatych godzinkach księcia de Berry znajduje się miniatura ukazująca symboliczny kolisty ogród rajski otoczony murem z wielką gotycką bramą i z Fontanną Życia pośrodku ujętą w monumentalną konstrukcję gotycką (tabernakulum). Jak pisze Jean Hani, przenikanie się koła i kwadratu („kwadratura koła”) w średniowiecznej sztuce sakralnej, stanowiło

${ }^{80}$ Ikonografia muzyki rajskiej przybiera najczęściej postać chórów anielskich, czego dobrym przykładem może być Ołtarz Gandawski Huberta i Jana van Eycków.

${ }^{81}$ Zauważmy, że muzyka była obszarem, w którym dochodzi do głosu proponowane przez św. Augustyna „piękno proporcji”. Por. W. Eborowicz, Z genealogii dialogu o muzyce, w: Św. Augustyn, Dialogi i pisma filozoficzne, przeł. D. Turkowska, t. IV, Warszawa 1954, s. 12.

82 Jak pisze J. T. Frazik: „Gotycki rysunek architektoniczny nie był oderwany od całej wiedzy i estetyki średniowiecznej. Odwrotnie, architekci korzystali z pitagorejskiej teorii liczby i platońskiej kosmologii. Analogicznie odnoszono się do muzyki łącząc ją z koncepcją kosmologiczną". Zob. J.T. Frazik, Ze studiów nad warsztatem architekta w średniowieczu, Kraków 1990, s. 34 .

${ }^{83}$ Por. Wizerunek Stwórcy jako Architekta lub Geometry: Bible moralisée, Biblioteka Narodowa w Wiedniu (Cod. 2554, fol.1); Bible moralisée, Bodleian Library w Oksfordzie (Ms. 270 b, fol. 1) i in.

${ }^{84}$ S. Kobielus, Człowiek..., dz. cyt., s. 46.

${ }^{85}$ Tamże, s. 50-51. 
łączenie nieba z ziemią, „doczesny obrót świata i jego zatrzymanie, które jest jednocześnie przeobrażeniem obecnego wieku w przyszły wiek" ${ }^{\prime \prime 6}$.

Szczególną postać średniowiecznej geometrii świętej przyjmowały labirynty na posadzkach katedr gotyckich, które służyły zdobywaniu raju niebieskiego (tzw. drogi jerozolimskie). Były to szlaki, które miały prowadzić na sposób duchowy do zdobycia ziemskiej Jerozolimy dla tych, którzy nie mogli wziąć udziału w wyprawach krzyżowych. Wierzono przy tym, że kto polegnie w Ziemi Świętej w walce z muzułmanami będzie zbawiony. Tak więc, wędrówkę wewnątrz labiryntu rozumiano jako rodzaj duchowej pielgrzymki, poszukiwania i odnajdywania szczęścia w wymiarze eschatologicznym, jako drogę do raju odzyskanego ${ }^{87}$. Do dzisiaj takie labirynty zachowały się m.in. w Chartres, Amiens, w Pawii, w San Vitale w Rawennie, czy w katedrze w Quedlinburgu ${ }^{88}$.

Łaciński neoplatonik Makrobiusz nazywał pierwotny rajski ogród „kosmiczną świątynią"; podobnie Euzebiusz z Cezarei ${ }^{89}$. Tę tradycję kontynuował Alan z Lille i inni filozofowie szkoły w Chartes. Pod wpływem apokaliptyki staro- i nowotestamentowej nastąpiło złączenie obrazu rajskiego ogrodu z Księgi Rodzaju z obrazem eschatologicznego niebieskiego Jeruzalem, co skutkowało wykształceniem się nowych schematów ikonografii ${ }^{90}$. Kosmiczna góra, na której Ezechiel

${ }^{86}$ J. Hani, Symbolika świątyni chrześcijańskiej, przeł. A.Q. Lavique, Kraków 1995, s. 26.

${ }^{87}$ Tamże, s. 100-101.

${ }^{88}$ Labirynty funkcjonowały w kulturze europejskiej niekiedy w postaci „zaczarowanego ogrodu”, o którym pisał Robert Mallet: „Damy przebiegające ogrodowe labirynty mogły sobie wyobrażać, że biorą duchowy udział w przeżyciach swych mężów lub adorujących je rycerzy. Święty Graal i Grób Chrystusa stanowiły cel na miarę silnych dusz, opętanych tragedią wygnania z Raju i potrzebą jego odzyskania, posuwających się aż do granic swoich możliwości". Zob. R. Mallet, Jardin et Paradis, Paris 1962. Cyt. za: Z. Żygulski jun., Obraz raju w sztuce islamu, w: Orient i orientalizm w sztuce. Materiały Sesji Stowarzyszenia Historyków Sztuki, Kraków, grudzień 1983, Warszawa 1986, s. 20.

${ }^{89}$ M. Borowska, Raj..., dz. cyt., s. 54.

${ }^{90} \mathrm{~W}$ interpretacji teologicznej i ikonograficznej rajski ogród zostaje utożsamiony zarówno z eschatologicznym Niebieskim Jeruzalem, klasztorem (wspólnotą zakonną), jak i całym Kościołem wojującym i triumfującym (w kategoriach teologii trydenckiej), tak jak to przedstawił w obrazie Źródło życia wiecznego mistrz Jan van Eyck. Tronujący Chrystus przedstawiony jest tu jako Pontifex w szatach papieskich, na bogatym tronie z 4 symbolami ewangelistów i posągami proroków w tabernakulach, po bokach Maryja i Jan - w ujęciu Deesis. U stóp Chrystusa Baranek Apokaliptyczny, poniżej którego znajduje się źródło życia wiecznego (w postaci fontanny). Fontanna ma formę monumentalnej gotyckiej wimpergi (przypominającej ówczesne sakraria służące do przechowywania Sanctissimum). W dolnym rejestrze mamy 
umieścił swój mesjanistyczny Eden o murach z cennych kamieni, przeistoczyła się w erze chrześcijańskiej w święte miasto Jeruzalem, niebieską Jerozolimę (Ap 21, 11-22). Warstwy „fundamentu pod murem Miasta zdobne są wszelkim drogim kamieniem", będą tam szmaragdy, topazy i jeszcze dziewięć innych rodzajów szlachetnych kamieni. Już na mozaice w kościele św. Kosmy i Damiana w Rzymie Baranek na skale i w aureoli to Baranek Apokaliptyczny; z tronu Boga i Baranka w niebieskiej Jerozolimie wytryskuje „rzeka wody życia” (Ap 22, 1). Co ciekawe, rzeki rajskie pojawiają się stosunkowo rzadko w ikonografii rajskiego ogrodu. Najstarsze przykłady tych scen nawiązują do raju eschatologicznego, do niebieskiego Jeruzalem - od Baranka stojącego na rajskiej górze (skale) wypływają cztery strugi oznaczające „rzekę wody życia”. Takie przedstawienia znajdujemy na przykład na czterech płytach podłogowych kolistego żyrandola („korony światła") cesarza Barbarossy w Akwizgranie, czy też na środkowej gałce relikwiarza św. Elżbiety w Marburgu. Mozaika w górnym rejestrze (w konsze absydy kościoła) kościoła św. Kosmy i Damiana w Rzymie wyraża mistyczną, transcendentną naturę Kościoła, którego głową jest Chrystus; Kościół w dolnym rejestrze zostaje przedstawiony w postaci baranków symbolizujących dwunastu apostołów „mała trzódka” skupionych wokół Paschalnego Baranka (Łk 12,32). Rajskie rzeki wypływające ze skały (tronu Baranka) przybierają nieraz znaczenia mistycznego jako wyobrażenie łaski Chrystusa ożywiającej Kościół Boży ${ }^{91}$.

\section{Ogród z kulturą, a artystę ze Stwórcą łączył pierwszy rosyjski humanista, siedemnastowieczny carski poeta, Symeon Połocki (1629-1680).}

wyobrażenie Eklezji (heraldycznie po prawej stronie) i Synagogi (po lewej) z arcykapłanem z zawiązanymi oczami (co oznacza, że naród wybrany nie rozpoznał swego Mesjasza i sam odciął się od źródła życia).

${ }^{91}$ Źródło Życia w centrum Raju rozmaicie je przedstawiano: albo jako zdrój, jako naczynie z którego piją zwierzęta albo jako bukłak czy fontannę. Często spotykamy personifikacje rajskich rzek, tak jak na wysklepkach sklepienia krzyżowego katedry w Cividale (XI w.). 
Ogród z kulturą, a artystę ze Stwórcą łączył pierwszy rosyjski humanista, siedemnastowieczny carski poeta, Symeon Połocki (1629-1680). W swoim zbiorze poetyckim "Ogród wielokwiatowy” (Wiertograd mnogocwietnyj) kunszt poetycki uznawał za echo "raju duchowego" i „ogrodu niebieskiego”. Nadawał nadto swej wyrafinowanej sztuce wersyfikatorskiej kształt wizualnego „ogrodu kwiecistego” urządzonego - jak sam pisał - na chwałę Stwórcy i dla pożytku duchowego ludzi. Kwiaty tego literackiego ogrodu miały przynieść pożytek dydaktyczny i słodycz duchową (duszewnoje usłażdienije) ${ }^{92}$. Połocki określał swoją pisarską tożsamość twórcy mianem „robotnika (trudnika) słowa”, „ogrodnika” przesadzającego do swojego ogrodu z duchowych i kwiecistych ogrodów (priebogatocwietnych wiertogradow) przeszłości, przesłodkie i pożyteczne dla duszy kwiaty ożywiające duszę (priesładostnyje duszepoleznyje cwiety usłażdienija duszeżiwatielnago ${ }^{93}$. Trud poety uważał za eksternalizację prawdziwego artyzmu, jako „przesadzanie korzeni i przenosienie nasion" (priesażdienije korniej i siemion) z europejskiego do rosyjskiego „ogrodu”, czyli na łono języka słowiańskiego ( $w$ domasznij mi jazyk słowienskij) ${ }^{94}$.

${ }^{92}$ Symeon Połocki w zbiorze poetyckim „Ogród wielokwiatowy” (Wiertograd mnogocwietnyj) nawiązującym formą literacką i treścią do średniowiecznych florilegiów. Za podstawę posłużyły wiersze napisane w różnym czasie. Praca nad zbiorem „Ogród wielokwietowy” trwała w latach 1677 - 1678. Zbiór, zgodnie ze scholastyczym schematem, miał nie tylko dawać rozrywkę i pouczać, ale posłużył za swoisty słownik encyklopedyczny. Stosowny do tego pomysłu materiał został podzielony na poszczególne rubryki według porządku alfabetycznego: „Aaron”, „Abel” itd. „Ogród wielokwiatowy” zachował się w kopiach przechowywanych w Dziale Rękopisów Państwowego Muzeum Historycznego w Moskwie, Sinodalnoje sobranije nr 288, 659 oraz w rękopisie w stylu kaligraficznym w półustawie w Dziale Rękopisów Biblioteki Akademii Nauk Federacji Rosyjskiej w Moskwie nr 31.7.3. W rękopisie wiersze nie zostały jeszcze ułożone według porządku alfabetycznego. Jedna z kopii była przygotowaniem do druku i posiada poprawki uczynione ręką Połockiego. Zob. I. P. Jeriomin, Poeticzeskij stil Simieona Połockogo, „Trudy Otdieła Driewnierusskoj Litieratury” Moskwa-Leningrad 1948, t. VI, s. 7-84; A. M. Panczenko, Słowo i Znanije w estietikie Simieona Połockogo. Na matieriale "Wiertograda mogocwietnogo", „Trudy Otdieła Driewnierusskoj Litieratury”, t. 25, Leningrad 1973. Por. W. W. Byczkow, Estietika pozdniej anticznosti, Moskwa 1982, s. 43.

${ }^{93}$ W zbiorze Połockiego „Ogród wielokwiatowy” tematowi pracy poświęcony został cały szereg wierszy: God wieka obraz, Prazdnowanije, Trud i wiele innych. W wierszu „Orzeł rosyjski" wypowiedział myśl, że pracowitym winien być sam władca:

„Przez pracę bogactwo i sława przychodzi

Trud wieńcem carskim wiele nagrodzi."

Zob. Orieł rossijskij. Tworienije Simieona Połockogo, (red.) N.A. Smirnow, Sankt-Pietierburg 1915, s. 44.

${ }^{94}$ Zob. W.K. Bylinin, W.A. Grichin, Simieon Połockij i Simon Uszakow: K problemie estietiki Russkogo barokko, w: Barokko w sławianskich kulturach, Moskwa 1982, s. 210. 
Połocki podkreślał autonomiczną rolę artysty, jego „stwórczą” funkcję, tworzącego na wzór Boga i na chwałę Boskiego Stwórcy. W średniowiecznych i nowożytnych dyscyplinach naukowych nieraz Boga nazywano Poetą lub Artystą; Bóg wszak podyktował ludziom natchnione wersety Biblii i w sposób mistrzowski zaplanował i stworzył świat. Mojżesz, Hiob, Dawid, Salomon i Izajasz byli poetami tworzącymi dzięki natchnieniu Boga. W średniowieczu poeta spełniał mistyczną rolę pośrednika między człowiekiem a Bogiem. Źródłem takiego rozumienia roli poety była sama Biblia, jako wielki poemat Boga-Stwórcy, który umieścił ją obok innego swojego dzieła - przyrody ${ }^{95}$. Połocki uważał, że wszystkie rośliny ogrodowe stanowią część wielkiej księgi danej przez Boga człowiekowi jaką jest natura, którą Bóg dał we władanie człowiekowi. Analogicznie, kunszt artystyczny według Połockiego realizował się w organizowaniu w jedność estetyczną duchowych i materialnych elementów, czyli w pięknym urządzeniu „ogrodu kultury”. Biegłość doświadczonego twórcy (chitrost' chudożnika iskusnago) Połocki stawiał wyżej, niż największe cuda przyrody. Pracę twórcy Symeon zestawiał z trudem Stwórcy, a z drugiej strony z pracą ogrodnika uprawiającego naturę i przekształcającego ją w kulturę. Twórca jak ogrodnik hoduje szlachetne kwiaty pośród dzikich traw. Świadom swego kunsztu artysta-ogrodnik okazuje się robotnikiem pokonującym naturę, wprowadzającym porządek i harmonię w swoim kulturalnym ogrodzie; tak postępuje artysta, który na podobieństwo do umiejętności hodowcy kwiatów, sadzącego według porządku pór roku i zasad agrarnych kwiaty, urządza „kulturalny ogród"96.

\section{PODSUMOWANIE}

Nie można przecenić znaczenia ogrodów w historii kultury światowej, wszak to one stanowiły miejsce powstawania i kształtowania się syntezy kultury agrarnej i intelektualnej ze względu na dokonująca się w tych miejscach sztukę uprawiania roślin (łac. cultus - „uprawa” - kultura), a także dogodne warunki środowiskowe sprzyjające rozwojowi twórczości i nauki. Obserwując rozwój historii ogrodów można stwierdzić, że każda epoka poprzez wnoszenie do założeń ogrodowych nowych elementów, sukcesywnie ubogacała sztukę kształtowania ogrodów. Od

${ }^{95}$ Filon z Aleksandrii nazywał świat „młodszym synem Boga”. Zob. Filon Aleksandryjski, O niezmienności Boga, w: Pisma, t. 1, przeł. S. Kalinkowski, Kraków 1994, s. 26.

${ }^{96}$ W.W. Byczkow, Estietika..., dz. cyt., s. 35. 
czasów starożytności rozwinęła się znacząco skala rozwiązań kompozycyjnych, poszerzyły się programy i zasoby środków, co pozwalało na coraz lepsze zagospodarowywanie naturalnej przestrzeni w odniesieniu do potrzeb użytkowych, utylitarnych i estetycznych. Równolegle do generowania określonych uwarunkowań społeczno-gospodarczych każda epoka historyczna jednocześnie stwarzała określone uwarunkowania w komunikowaniu określonych treści ewokowanych przez treści symboliczne ogrodów. Ogród już w zamierzchłych czasach przybrał postać symbolu skrywającego wiele różnych treści kulturowych. W symbolu znaczenie czegoś komunikuje się głębiej, niż można to wyrazić i pojąć w inny sposób; dzięki niemu zostają obudzone nowe impulsy w komunikowaniu myśli, człowiek czuje się dosięgnięty przez „inne”, które prowokuje, karmi i odsłania nieprzewidywalne horyzonty; otwiera się na syntezę, której nie wyczerpuje nawet najlepiej przeprowadzona analiza. Jej podstawy zostały stworzone już przed wiekami. Nie sposób nie wymienić w tym miejscu anonimowego tekstu bizantyńskiego Ogród symboliczny (XII w.) opublikowanego przez Margaret H. Thomson, który szczegółowo podaje i opisuje symbolikę ogrodu, rozmaitych roślin ogrodowych, żywiołów, ogrodnika, ogrodzenia itp. ${ }^{97}$

\section{Ogród już w zamierzchłych czasach przybrał postać symbolu skrywającego wiele różnych treści kulturowych.}

Ogród jako nośnik znaczeniowy szczęścia stał się w kulturze chrześcijańskiej pojęciem, w którym zawiera się sens wiecznej młodości, nieprzemijającej wiosny, dziewiczej natury, wytchnienia i odpoczynku, odosobnienia, radości czy satysfakcji duchowej i zmysłowej. Ogród to przestrzeń, w której przyroda zostaje wygrodzona, ujarzmiona, uporządkowana i wyselekcjonowana ${ }^{98}$. Ogród jest

${ }^{97}$ Zob. M.H. Thomson (ed.), The Symbolic Garden. Reflections Drawn from a Garden of Virtues. A XIIth Century Greek Manuscript, North York, Ont. 1989; Por. A. Littlewood, H. Maguire, J. Wolschke-Bulmahn, Byzantine Garden Culture, Washington 2002.

${ }^{98}$ J. E. Cirlot, Słownik symboli, przeł. I. Kania, Kraków 2000, s. 283 (hasło: Ogród). W świętej księdze zaratustrian, Aweście, rajski ogród nosi miano pairi-daeza, co oznacza dosłownie „miejsce ogrodzone”, „ogród”, które następnie przeszło do języka późnobabilońskiego 
miejscem, w którym zaznaje się odpoczynku (otium); dlatego w średniowieczu był przeciwstawiany miastu, jako miejscu pracy i handlu (negotium) ${ }^{99}$. W chrześcijańskim kodzie kulturowym ogród jest znakiem szczęścia i przyjemności (hortus voluptatis), ale także posiada znamię miejsca odosobnienia, bezpieczeństwa i tajemnicy. Jako rzeczywistość obwarowywana murem lub płotem (hortus conclusus), zaopatrzona w wąską bramę strzeżoną przez realne lub mistyczne stwory (np. węże, serafiny), bywa owiana tajemnicą stając się znakiem wiedzy hermetycznej. Mur lub płot okalający ogród jest symbolem ograniczenia w dotarciu do środka i do istoty rzeczy. Na płaszczyźnie symbolicznej wchodzenie do rajskiego ogrodu oznacza trud ponoszony w celu osiągania wyższego stopnia rozwoju intelektualnego i duchowego; może też być symbolem emocjonalnego opanowania i wstrzemięźliwości, jak również panowania rozumu nad uczuciami. Dzięki temu ogród stał się w komunikacji kulturowej znakiem tajemnicy, wiedzy, wybraństwa, miejscem elitarnym ${ }^{100}$.

\section{BIBLIOGRAFIA}

Abramowicz D.I., Issledowanije o Kijewo-Pieczerskom Patierikie kak istoriko-litieraturnom pamiatnikie, Sankt-Pietierburg 1901.

Antologia mistyków franciszkańskich, red. S. Kafel, t. 3, Warszawa 1987.

Św. Augustyn, Przeciw akademikom, przeł. K. Augustyniak, w: Dialogi filozoficzne, t. I, Warszawa 1953.

Basiura T., Ogród Maryi. Atlas roślin maryjnych, Kraków 2018.

Borowska M., Raj - miejsce czy droga? Wyobrażenia późnośredniowieczne a myśl współczesna, Izabelin 2004.

Byczkow W.W., Estietika pozdniej anticznosti, Moskwa 1982.

Bylinin W.K., Grichin W.A., Simieon Połockij i Simon Uszakow: K problemie estietiki Russkogo barokko, w: Barokko w sławianskich kulturach, Moskwa 1982.

\footnotetext{
w postaci pardisu. Izraelici przebywając na wygnaniu w Babilonii widzieli w kraju swoich ciemiężycieli piękne ogrody wraz z którymi przejęli określenie pardes, a tłumacze Septuaginty przetłumaczyli to na grecki jako paradeisos. W języku greckim pojęcie to otrzymało wyraźny wydźwięk szczęścia, przyjemności, rozkoszy. We frazie Septuaginty paradeisos tes tryfes rajski ogród stał się dosłownie „ogrodem rozkoszy” (łac. hortus voluptatis).

${ }^{99} \mathrm{~W}$ licznych dziełach sztuki i literatury europejskiej zawarta została bogata symbolika chrześcijańska. Połączenie w badaniach nad ogrodami obszaru botaniki i sztuki, historii i filozofii, architektury i teologii oraz innych dyscyplin znajduje uzasadnienie i wykorzystanie we współczesnej humanistyce. Por. M. Borowska, Raj..., dz. cyt., s. 8.

${ }^{100}$ Leksykon Symboli (Herder), przeł. J. Prokopiuk, Warszawa 2009, s. 200.
} 
Chrobok A., Historia ogrodów, cz.6: Ogrody renesansu http://www.miejskiogrodnik.pl/ porady-dla-ogrodu/item/490-historia-ogrodow-cz6-ogrody-renesansu, dostęp 31.08.2018.

Cirlot J.E., Słownik symboli, przeł. I. Kania, Kraków 2000.

Danielou J., Trójca Święta i tajemnica egzystencji, przeł. M. Tarnowska, Kraków 1994.

Dąb-Kalinowska B., Ziemia, piekło, raj, Warszawa 1994.

Delumeau J., Historia raju. Ogród rozkoszy, przeł. E. Bąkowska, Warszawa 1996

Dudek-Klimiuk J., Ogród botaniczny Uniwersytetu Warszawskiego - ogród pamięci i wyobraźni, „Architektura” 2-A/2012.

Eborowicz W., Z genealogii dialogu o muzyce, w: Św. Augustyn, Dialogi i pisma filozoficzne, przeł. D. Turkowska, t. IV, Warszawa 1954.

Filon Aleksandryjski, O niezmienności Boga, w: Pisma, t. 1, przeł. S. Kalinkowski, Kraków 1994.

Fortyniuk K., Ogrody barokowe, http://www.ogrodyprojekty.com/pl_ogrody-barokowe,74.html, dostęp 31.08.2018.

Forte B., Maryja ikona tajemnicy, przeł. B. Widła, Warszawa 1999.

Frazik J.T., Ze studiów nad warsztatem architekta w średniowieczu, Kraków 1990.

Garin E., Moyen Age et Renaissance, Paris 1969.

Guzikowska-Konopińska E., Ogród japoński, Warszawa 2013.

Hani J., Symbolika świq̨tyni chrześcijańskiej, przeł. A.Q. Lavique, Kraków 1995.

Hodor K., Podmiejskie rezydencje dworsko-ogrodowe w ksztattowaniu krajobrazu mikroregionu Rowu Krzeszowickiego, Kraków 2011.

Horacy, XVI epoda, przeł. T. Węclewski, Wielka Literatura Powszechna, t. V (Antologia. Cz. I. Literatury: chińska, japońska, indyjska, sumero-akkadzka, babilońska i asyryjska, egipska, starohebrajska, żydowska, arabska, perska, turecka, grecka, rzymska, łacińska wieków średnich, włoska, staro- i nowoprowancka, francuska), Nakładem Księgarni Trzaski, Everta i Michalskiego, Warszawa 1930.

Impelluso L., Ogrody i labirynty, przeł. A. Wójcicka, Warszawa 2009.

Jagla J., Święte czy diabelskie? Symboliczny wizerunek roślin kłujących, kolczastych i ciernistych $w$ malarstwie europejskim, w: Rośliny lecznicze w kulturze, nauce i sztuce. Materiały z konferencji z okazji 25-lecia „Ogrodu roślin zdatnych do zażycia lekarskiego” w Muzeum Rolnictwa im. Ks. K. Kluka w Ciechanowcu, Ciechanowiec 2009.

Jeriomin I.P., Poeticzeskij stil Simieona Połockogo, „Trudy Otdieła Driewnierusskoj Litieratury", t. VI, Moskwa-Leningrad 1948.

Klaja M., Idea szczęścia u św. Tomasza z Akwinu, „Alma Mater”, http://www2.almamater. uj.edu.pl/102/20.pdf; dostęp 5.06.2018.

Kobielus S., Człowiek i ogród rajski w kulturze religijnej średniowiecza, Warszawa 1997.

Kobielus S., Florarium christianum. Symbolika roślin - chrześcijańska starożytność i średniowiecze, Kraków 2006.

Kopaliński W., Słownik mitów i tradycji kultury, Warszawa 1987.

Kopiński K., Wiszqce ogrody Semiramidy, http://www.7cudow.ovh.org/stare-cuda/wiszace-ogrody-semiramidy.html, dostęp 31.08.2018. 
Koszkało M., Koncepcja woli według św. Augustyna - perspektywa antropologiczna, „Roczniki Filozoficzne", t. LXIV nr 3/2016.

Leach E., Kultura i komunikowanie. Logika powiqzań symbolicznych. Wprowadzenie do analizy strukturalnej $w$ antropologii społecznej, przeł. M. Buchowski, Warszawa 2010.

Leksykon Symboli (Herder), przeł. J. Prokopiuk, Warszawa 2009.

Littlewood A., Maguire H., Wolschke-Bulmahn J., Byzantine Garden Culture, Washington 2002.

Majdecki L., Historia ogrodów, Warszawa 1981.

Mallet R., Jardin et Paradis, Paris 1962.

Misiąg-Bocheńska A., Arrasy biblijne. Sceny z Księgi Genesis, w: Arrasy Wawelskie, Warszawa 1994.

Mitkowska A., Siewniak M., Tezaurus sztuki ogrodowej, Warszawa 1998.

Morozow A.A., Iz istorii osmyslenija niekotorych emblem w epochu Renesansa i Barokko, w: Mif, Fołkłor, Litieratura, Leningrad 1978.

Orieł rossijskij. Tworienije Simieona Połockogo, N.A. Smirnow (red.), Sankt-Pietierburg 1915.

Panczenko A.M., Słowo i Znanije w estietikie Simieona Połockogo. Na matieriale „Wiertograda mogocwietnogo”, „Trudy Otdieła Driewnierusskoj Litieratury”, t. 25, Lenin$\operatorname{grad} 1973$.

Peters J., Göbekli Tepe: Agriculture and Domestication, w: The Archeological Record. https://www.researchgate.net/publication/260198406_Gobekli_Tepe_Agriculture_and_Domestication, dostęp 16.08.2018.

Pierietc W.N., Kijewo-Pieczerskij Patierik w polskom i ukrainskom pieriewodie, w: IV Mieżdunarodnyj sjezd sławistow. „Słowianskaja fiłołogija”, wyd. III, Moskwa 1958.

Platon, Sofista i Polityk, przeł. W. Witwicki, Warszawa 1956.

Poniatowski Z., Mały słownik religioznawczy, Warszawa 1969.

Rozmarynowska K., O wzajemnych relacjach człowieka, przyrody, ogrodu i miasta, „Estetyka i krytyka" 2007, nr 12 (1/2007).

Rymkiewicz J.M., Myśli różne o ogrodach, Warszawa 1968.

Schmidt K., Göbekli Tepe. Eine Beschreibung der wichtigsten Befunde erstellt nach den Arbeiten der Grabungsteams der Jahre 1995-2007, w: "ArcheNova", Erste Tempel - fruehe Siedlungen. 12000 Jahre Kunst und Kultur. Ausgrabungen und Forschungen zwischen Donau und Euphrat, Isensee - Oldenburg 2009.

Schmidt K., Göbekli Tepe - the Stone Age Sanctuaries. New results of ongoing excavations with a special focus on sculptures and high reliefs, "Documenta Praehistorica", vol. XXXVII (2010).

Seibert J., Leksykon sztuki chrześcijańskiej. Tematy, postacie, symbole, przeł. D. Petruk, Kielce 2007.

Simson 0. Von, Katedra gotycka. Jej narodziny i znaczenie, przeł. A. Palińska, Warszawa 1989. 
Sobolewskij A. I., Pieriewodnaja litieratura Moskowskoj Rusi XIV-XVII wiekow, Sankt-Pieterburg 1903.

Stępień T., Wprowadzenie do antropologii filozoficznej św. Tomasza z Akwinu, Warszawa 2013.

Sudak B., Matematyczna koncepcja muzyki, Zielona Góra 1992.

Thomson M.H. (ed.), The Symbolic Garden. Reflections Drawn from a Garden of Virtues. A XIIth Century Greek Manuscript, North York, Ont. 1989.

Titow F., Tipografija Kijewo-Pieczerskoj ławry. Istoriczeskij oczerk (1606-1616-1721), t. I, Priłożenija, Kijew 1918.

Urbaniak T., III Studencka Sesja Naukowa na temat filozoficznych koncepcji szczęścia, „Studia Philosophiae Christianae" 10/2, 1974.

Warner M., Sola fra le donne. Mito e culto di Maria Vergine, Palermo 1980.

Św. Tomasz z Akwinu, Suma Teologiczna, t. 9: Cel ostateczny, czyli szczęście oraz uczynki ludzkie, przeł. W.F. Bednarski OP, Londyn [b.r.w.], http://www.katedra.uksw.edu.pl/ suma/Suma\%209.pdf; dostęp 5.06.2018.

Wilder J., Ogród doskonały, Warszawa 2013.

Wysłouch S., Literatura a sztuki wizualne, Warszawa 1994.

Zachariasz A., Zieleń jako współczesny czynnik miastotwórczy ze szczególnym uwzględnieniem parków publicznych, Kraków 2006.

Zemanek B., Ogród - raj odzyskany czy substytut natury, w: Ogród Pana. XVIII Międzynarodowe Seminarium Sacrum i Przyroda, red. J. Brusiło, Kraków 2010.

Żygulski Z. jun., Obraz raju w sztuce islamu, w: Orient i orientalizm w sztuce. Materiały Sesji Stowarzyszenia Historyków Sztuki, Kraków, grudzień 1983, Warszawa 1986.

\section{Biogram}

Norbert Mojżyn, historyk sztuki i teolog kultury, pracuje na UKSW, zajmuje się komunikacją wizualną i kulturową. 